\title{
Horticulture, Horticultural Science, and 100 Years of ASHS
}

\author{
Jules Janick \\ Department of Horticulture and Landscape Architecture, Purdue University, \\ 625 Agriculture Mall Drive, West Lafayette IN 47907-2010 \\ Irwin L. Goldman \\ Department of Horticulture, University of Wisconsin, Madison, 1575 Linden Drive, Madison WI 53706-1590
}

In 1903, the Wright brothers severed the surly bonds of earth and initiated the age of flight. In the same year, a New York pomologist, S.A. Beach, took on the haughty academic botanical establishment from their airy heights, and brought us down to earth-establishing the Society for Horticultural Science, later renamed the American Society for Horticultural Science (ASHS). Fifty years later, Liberty Hyde Bailey when reminiscing, expressed the following thoughts (Howlett 1953): "This society was formed of necessity. There was no meeting ground within the framework of state or local horticultural societies for the scientists-no place for him and his colleagues to meet. [botanical societies?] That's why the Society for Horticultural Science was born. To many botanists I was not a scientist. I didn't talk just about the influence of light on plant growth, I talked about its influence on beans. I didn't talk about factors involving plant breeding, I talked about the problems and results ofbreeding squashes. I talked about the need for scientific work on horticultural problems. But it was not considered a science. The botanist spoke of pure science as if some science was impure. Fifty years ago knowledge from the applied studies was not acceptable to the botanists because it was not botany. And in a sense they were right. It was horticulture, the opening of a door to a new dawn!"

This year we celebrate the centennial of a momentous event that has changed forever our lives and our professions. The present review was written to commemorate this event and is presented in two parts: a general review of the state of horticulture and horticultural science with emphasis on the last 100 years, and a review of 100 years of ASHS.

\section{THE HISTORY OF HORTICULTURE}

\section{Horticulture: The First 10,000 Years}

Horticulture is truly an ancient pursuit. Some 10,000 years ago, our brilliant forebears discovered the horticultural craft secrets that are the basis of our profession. They initiated a revolution that changed forever the destiny of humans from scavenging, collecting, and hunting to agriculture. We all are the heirs and beneficiaries of this legacy from the past. Our roots derive from prehistoric gatherers, Sumerian, Egyptian, and Chinese farmers, Hellenic root diggers, medieval peasants, and gardeners everywhere who devised practical solutions to problems of plant growing for food, medicine, fiber, and shelter. The accumulated successes and improvements passed orally from parent to child, from artisan to apprentice, and became embedded in human consciousness via legend, craft secrets, and folk wisdom. It was stored in tales, almanacs, herbals, and histories and has become part of our common culture. More than practices and skills were involved as improved germplasm was selected and preserved via seed and graft from harvest to harvest and generation to generation. An array of technological approaches from primitive tools fashioned during the Bronze and Iron Ages through the development of the horticultural arts - irrigation, propagation, cultivation, drying and fermentation - were devised to accommodate the needs and desires of humankind. The sum total of these technologies make up the traditional lore of horticulture. It represents a monumental achievement of our forebears, unknown and unsung (Janick, 1989a).

The scientific tradition is not as old but is ancient nevertheless. Its beginnings derive from systematic attempts to discover rational explanations for nature. Science, from the Greek to know is in reality a method for accumulating new information about our universe. The driving imperative is the desire to understand. If necessity is the mother of invention, curiosity is the mother of science. The scientific method involves systematic experimentation, rationality, inductive reasoning, and constant reformulation of hypotheses to incorporate new facts. When new explanations of natural phenomena are accepted, they nevertheless must be considered not as dogma but as tentative approaches to the truth and subject to change. The process is cumulative and science is alive only when it grows. When any society claims to know the complete truth such that further question is heresy, science dies.

Horticultural knowledge accumulation has always been in a state of tension between the mundane empiricism of the gardening arts discovered by generations of growers in contrast to information generated by scientists, often academics, sometimes indifferent to the uses of their discoveries and often obsessed by the irrelevant. In the 1900s, horticultural science was considered an oxymoron. One hundred years later, we are a Society that rejects this taunt and have demonstrated that horticultural science is a truly humanistic plant science, concerned with all information relevant to the interaction of humans and the plants that serve them. Our goal is the betterment of humankind.

Throughout this paper, we will discuss a number of significant advancements in science that have been made by horticulturists or by plant scientists using horticultural plants and later applied to agriculture and other fields. For example, Gregor Mendel's groundbreaking discovery of the principles of heredity in a monastery garden led to what might be considered the most important scientific revolution in modern times: the flow of genetic information from generation to generation. Photoperiodic effects on plant growth, first reported by W.W. Garner and H.A. Allard on a number of horticultural crops in 1920, set the stage for understanding the relationship between crop production, light, and temperature. Fieldlevel photosynthetic rates were first measured by A.J. Heinicke and N.F. Childers in the 1930s using an apple-tree model. These concepts were later applied to many agricultural and ecological situations to evaluate carbon dioxide fixation and photosynthetic rates. L.R. Jones and J.C. Walker developed the concept of genetic control of plant disease resistance in their work with cabbage, leading to widespread efforts to use breeding techniques to obtain host plant resistance. H.A. Jones and A.F. Clarke discovered the cytoplasmic-genic system of hybrid seed production in onion, which revolutionized in F1 hybrid crop development. Particleacceleration technology, in which DNA is blasted into plant tissue in order to produce transgenic plant cells, was invented by the horticulturist John Sanford in 1987.

Few scientific fields have captured the imagination as has horticulture, perhaps because of its centrality to the development of human culture. Biblical and other religious texts are filled with horticultural metaphors, such as the placement of Adam and Eve in the Garden of Eden near the Tree of Knowledge, the olive branch as a symbol for peace, and Noah's cultivation of a vineyard as his first act after the flood. We speak of a renaissance in events as a flowering and the end of innocence as a deflowering. The education of our youth involves, appropriately, a garden of children, or kindergarten. We cultivate relationships and speak of our hard work bearing fruit, certain people as late bloomers, or others as wall flowers, or worse, gone-to-seed. Moving to a different location marks us as transplants, but staying put means we are putting down roots. Many of our best thinkers have communicated complex concepts with such horticultural metaphors. Charles Darwin used the branching tree in describing the process of evolution in nature. In his vision, the branches represent phylogenetic patterns of lineage, and the dropped branches and twigs represent extinction. This tree metaphor for what Darwin called descent with modification has completely permeated biological science and popular culture. Horticulture and its practices are woven into our consciousness and have become part of the fabric of our language and thought.

\section{Nineteenth Century Horticulture}

The horticultural information and lore that was available in the U.S. at the beginning of the 20th century was prodigious, although its application seems primitive by today's standards. Practically all 
horticultural crops - fruit, vegetables, ornamentals - we now use were known through generations of explorers, missionaries, plant hunters, and immigrants who brought in germplasm from all over the world. It is indeed remarkable how few of our horticultural commodities are native to North America, and how much horticulture itself was dependent on international trade, exploration, and immigration. The ancient horticultural arts including cultivation and irrigation, pruning and training, thinning and girdling, seed and vegetative propagation, storage and marketing were part of a thriving industry. However, there were tremendous problems with losses at all levels of the production chain due to diseases, pests, and unknown maladies; poor quality, low yields, and lack of product uniformity; as well as seasonal gluts and shortages. There were many unanswered problems: why cultivars seem to run out, why some plants failed to flower, why some fruit did not store well. Despite an active seed and nursery industry there was no rationality or predictability in crop improvement.

Liberty Hyde Bailey's Cyclopedia of Horticulture in 1914 was a massive work that is a repository of late 19th century information. We still read it and marvel at the extent of what was known. Horticultural science in the last 100 years did not start from ground zero but on a firm foundation of what we now call the Old Horticulture.

Bailey's opus describes the tremendous wealth of information that had been generated during the 19th century. The period from 1840-1940 in the U.S. has been called the Agricultural Revolution by more than one agricultural historian (Edwards, 1940). While this is certainly true for agriculture, it is perhaps most true for the entire economic development of the U.S. during this period. From 1860-1914, the population of the U.S. grew from 31.3 million to 91.9 million, including 21 million immigrants. During this same period, the number of workers grew by $700 \%$, the rate of production by $2000 \%$, and investment capital by $4,000 \%$. Thus, the U.S. was poised for a major economic change that had implications for many sectors, including agriculture. The transformation of the agricultural landscape was depicted by Schmidt (1930): "Agriculture was transformed from a simple, pioneer, and largely self-sufficing occupation into a modern business organized on a scientific, capitalistic, and commercial basis; industry definitely underwent the change from hand labor in the home to machine production in the factory. And the local market was transformed into the world market. This threefold revolution in agriculture, industry, and commerce is the key to the study of the recent history of the United States."

The primary forces behind the Agricultural Revolution between 1840 and 1940 were 1) the transition from public to private ownership of land, 2) the expansive westward settlement of the U.S., 3) the invention and popularization of farm machinery, 4) the development of transportation facilities for agricultural products, 5) the transition of the industrial sector from farm to factory, 6) the significant expansion of foreign and domestic markets for agricultural products, and 7) the establishment and support of public agencies for agricultural research and scientific advances relevant to agriculture. While each of these forces has obvious antecedents in the agriculture of today, the continued scientific and technological advances that fuel agricultural development are the primary subject of this review.

In 1900, the farm population of the U.S. was 29 million comprising $39 \%$ of the population. Nonfarm families spent $25 \%$ of their income for food. Horticulture was a strong force in American agriculture, with millions of home gardens and hundreds of thousands of small market gardens. The U.S. was coming out of the farm depression of 1898 and things were looking up. This feeling of progress was based on the tremendous technological changes taking place in communication, transportation, and in a series of inventions such as the electric light, the motor car, the telegraph, and coast-to-coast railroads that altered the way ordinary people lived. However, while the industrial revolution had transformed America, it had relatively little impact on agriculture. The Agricultural Revolution was to be a truly 20th century phenomenon (Paarlberg and Paarlberg, 2000).

Afarmer from biblical times miraculously transported to an American farm in the year 1903 would have recognized and known how to use most of the tools he saw the hoe, the plow, the harrow, the rake with animal power fueled by oats and hay. Most of horticulture was an adjunct of the family farm, but large horticultural operations were emerging in the western U.S. Produce was seasonal and storage facilities were primitive.
The family farm was one of unending toil. Production was low and losses were severe due to diseases and pests.

The 20th century breakthroughs in agriculture, which were to have explosive consequences, had many causes including advances in science in general. Of particular significance to horticultural science in the U.S. was the establishment of the U.S. Department of Agriculture (USDA) in 1862, announced in President Lincoln's first communication with Congress. Beset by many administrative problems in the early years, the USDAmade significant headway in advancing agricultural science during the latter part of the 19th century. Beginning with a Division of Chemistry, the USDA expanded to soils and fertilizers, analyses of the relative composition of plants raised on various soils of the U.S., investigation of food and drug adulteration, and the manufacture of sugar. Later, an entomology branch was added, and in 1882, the Congress made its first appropriation for agricultural research in the form of a $\$ 20,000$ annual grant for investigating insects injurious to agriculture.

But the real lubricant and hatchery for the 20th century revolution in agriculture was to be found in the establishment of people's university known as the Land Grant colleges (Kerr, 1987). This occurred as a result of the Morrill Act signed by President Abraham Lincoln in 1862, emphasizing but not restricted to agriculture and the mechanical arts. This proved to be one of the greatest pieces of legislation enacted. The Land Grant colleges were established with little national coordination among their agricultural programs. To serve this need, agriculture experiment stations were formed. Their purpose was to link the work of state colleges with national priorities. The first experiment station was established in Connecticut in 1875, and by 1880 there were many such stations at Land Grant colleges.

The HatchAct of 1887 institutionalized the federal and state experiment station systems with state administration in the Land Grant colleges, a system that continues to this day. The Smith-Lever act of 1914 established a national system for extension that developed into a state-supported cooperative extension program. The trinity of research, teaching, and extension carried out by Land Grant colleges was to have a profound effect on agriculture. Most important, it transformed agriculture, of which horticulture was a significant part, into an academic discipline. Academic horticulture in the U.S. strove to break away from the empiricism of the past, and to devise explanations for traditional horticulture lore in order to solve the enormous problems faced in growing and distributing horticultural products. From the beginning, it was inclusive, drawing little distinction between food for the body and food for the soul, including ornamentals and landscape plants, medicinal and aromatic plants, crops considered commodities, and foods of health and delight.

The beginnings of horticulture as a science can be traced to founding of the Horticultural Society of London in England in 1806, subsequently the Royal Horticultural Society (Fletcher, 1969). In the early years, the society was led by Thomas Andrew Knight (1759-1838) and later by John Lindley (1799-1865), author of a book presciently titled The Theory of Horticulture (1840). In the U.S., state horticulture societies developed in the 19th century. For example, the Fruit Grower's Association of Wisconsin was organized in 1853 at Whitewater, Wis. Characteristic of these state-level activities was a focus on fruit and vegetable crops rather than ornamental horticulture. This was due to a desire to provide adequate food for the settlers and test the limits of the new climate with respect to crop production. The American Pomological Society, a national organization devoted to fruit growing, was formed in 1848.

Despite all this activity at the local level in many states and a thriving horticultural industry, there was no national society devoted to all of horticulture, much less horticultural science. In fact, horticulture and agriculture were not considered scientific at all, and the haughty botanists disdained the Mother of Science. Into this maelstrom came Spencer Ambrose Beech, a pomology professor in Geneva, N.Y., who made the decision to found a horticulture society devoted to science. The origin and evolution of this society will be discussed in the second part of the review.

\section{YEARS OF HORTICULTURE SCIENCE}

Horticulture has undergone cataclysmic changes in the last 100 years. These will be discussed in terms of commodities and disciplines in other papers presented in this centennial meeting. Here, we discuss changes in 
the broad terms of three revolutions: mechanical, chemical, and biological. The dramatic changes brought about by these technologies were to spawn enormous progress in horticulture and horticultural science.

\section{The Mechanical Revolution}

Mechanical devices were inherent in agriculture from its very beginnings in order to facilitate animal traction, cultivate crops, and to lift and transport water for irrigation. Although those devices underwent continual improvement over the millennia, they remained essentially similar in concept. The life of a farmer was one of drudgery and toil. In the early 19th century, mechanical advances such as McCormick's reaper and Eli Whitney's cotton gin were to profoundly affect U.S. agriculture. Steam-powered threshers and tractors were developed, but the engines were costly to operate and required tenders for water and coal. They were dangerous to operate and created fire hazards for fields and farmstead. It was the gasoline engine that was behind the Mechanical revolution in agriculture in the 20th century.

THE GaSOLInE ENGINE. In 1892, John Froelich built the first successfully operating gasoline tractor, concurrent with the gasoline-powered automobile. The iron beast took over and there soon were scores of companies developing farm tractors. In 1923, the Farmall, a tricycle-type row-crop machine produced by International Harvester marked the agricultural transition form horse to machine. In the 1930s the invention of the power take-off permitted the tractor to be the basic farm machine able to power a score of other operations. In the U.S., farm horses peaked in 1919 (26 million) but dropped to 4 million by 1955 , many of which were used for recreational purposes. From 1940 to 1950, tractors increased from 1.6 to 3.4 million. In the next 50 years, the gasoline engine, the tractor, and a thousand modifications were to become increasingly complex. New technology, dubbed precision agriculture, combines mechanical devices with electronic analytical instrumentation, including global positioning systems, to adjust application geared to each plant and location.

ConTrolled-ENVIRONMENT HORTICULTURE. Attempts to control the crop environment have precedents that date to antiquity. Pliny the Elder discusses a greenhouse (specularia) using transparent stone: (mica) to force cucumbers beloved by the emperor Tiberius. In the 18th century, cold frames were developed to force seedlings using heat generated from rotting manure. The glass greenhouse, based on an iron superstructure and heated by steam, was developed in the 19th century. Elaborate orangeries and conservatories were built on the estates of the wealthy and in botanical gardens. By the beginning of the 20th century, a prosperous industry developed for the production of cut flowers, bedding plants, and a few vegetables. In the first half of the 20th century, changes included improved construction, metal replacing wood glazing, better heating, a shift to oil and gas, and fan-and-pad cooling, but little essential basic change.

Artificial lighting in greenhouses has had a profound effect on horticultural science and crop production over the past 100 years. The roots of this technological innovation can be found in Liberty Hyde Bailey's 1891 publication in the Cornell University Agricultural Experiment Station Bulletin series titled "Some Preliminary Studies on the Influence of the Electric Arc Lamp upon Greenhouse Plants” (Wilcox-Lee, 1989). This paper reports work conducted on the feasibility of using electric lights in greenhouse environments for vegetable production. Bailey was the first U.S. scientist to conduct research on horticultural crop production using electric lights. Although there were European precedents for this kind of work, they were primarily concerned with physiological effects of light. Bailey's focus was pragmatic, and it also attempted to answer the question of whether electric lights were injurious to plants, as was believed at the time. Bailey concluded that light caused more rapid maturation in some plants and suggested that it might be useful one day in crop production. He also noted that light affected crop species differentially, causing undesirable bolting in some. The mysterious effects of photoperiodism remained unknown until Garner and Allard's pioneering work some 30 years later.

Once the effects of light were understood at a practical level, horticulturists began to manipulate the kinds and amounts of light in order to influence crop production. One horticultural triumph in this area was the discovery that light exclusion and a resulting shortened daylength could hasten flowering in ornamental plants. This discovery resulted in the birth of the international chrysanthemum industry. The seminal work in this area by Kenneth Post in 1934 in a New York State Experiment Station
Bulletin "Production of Early Blooms of Chrysanthemums by the Use of Black Cloth to Reduce the Length of Day" (Langhans, 1989). Post was aware that chrysanthemum was a plant that flowered in response to specific daylengths, but he struggled with how to exclude light in order to promote flowering. Post experimented with different types of cloth, finally settling on sateen, a tightly woven cloth that satisfactorily excluded light. He demonstrated the value of covering the plants beginning at 6 PM until 9 $\mathrm{AM}$, which allowed for cut-flower production on a year-round basis using relatively inexpensive and simple materials. This gem of horticultural science, created a multi-million dollar horticultural industry.

Research in Kentucky by horticulturist E.M. Emmert in the 1950s with polyethylene plastic film had a profound effect on world horticulture. The new technology dubbed plasticulture has been used for greenhouse covers, soil mulch, and various crop tunnels. The greatest development first occurred in subtropical climates for winter production, especially Spain and Israel. The plastic greenhouse has had a great effect in China where there presently are about 600,000 hectares of plastic greenhouses for vegetable production.

Automatic controls for the greenhouse environment became common place in the last 25 years, and greenhouses increasingly resemble automatic plant factories with climatic control similar to phototrons, the sine plus ultra of environmental control. Artificial lighting and automatic covers for daylength modification, automatic temperature and humidity control, automatic flat and pot filling, mechanized seeding and transplanting, pot spacing and distribution, are now found in many modern greenhouses but power costs and capital requirements are the main constraint. The emergence of the tomato and cucumber industry in Ontario, Canada, is an example of progress achieved with the combination of horticultural science and energy subsidization.

IRRIGATION. Irrigation technology always has been a basic part of horticulture. In the 19th century, irrigation in the western states was still based on furrow systems and gravity flow from canals, much as it had been since antiquity. Irrigation technology was first enhanced with the development of fixed sprinkler-irrigation systems, and then completely transformed in the more humid areas of the country with the development of light-weight, portable, aluminum pipe. In addition to moveable pipe, the development of center-pivot irrigation systems was to have a large and significant impact on vegetable and fruit production in the western U.S. and in many other parts of the country where large scale crop production was under development. These systems make use of a stationary pivot point for an irrigation system comprised of a $360^{\circ}$ rotating sprinkler arm on wheels.

A new technology called drip or trickle irrigation that was developed for semi-arid areas had perhaps the largest impact on irrigation for horticultural crops in all climates. Antecedents included perforated pipe buried beneath the soil, used in the U.S. and Australia, as well as the Chapin system to water individual pots in greenhouses via individual plastic tubes (so called spaghetti tubes) in the 1950s. In the early 1960s, work by Goldberg and Shmueli in the Arava desert in southern Israel demonstrated that a trickle-irrigation system installed on the soil surface worked exceptionally well in producing vegetable crops, even with saline water (Elfving, 1989). The system relied on lightweight plastic materials developed during and after World War II, and was responsible for the greening of a formerly unproductive environment.

The use of irrigation for frost control was to have a major impact on fruit production and out-of-season vegetable production. Attempts to control ice formation on fruit and vegetable crops received widespread public attention with the development of a genetically engineered bacterium known as ice-minus in the 1980s. The idea was to engineer the ice-nucleating bacterium Psuedomonas syringe to prevent its ability to initiate ice crystals. Because it was one of the first products of the new biotechnology industry, public scrutiny was at an all-time high, particularly when scientists in what appeared to be outfits suitable for a lunar landing were pictured spraying genetically engineered bacteria in strawberry fields in northern California. Although a fascinating scientific discovery, the deployment of nonice-nucleating bacteria into the environment did not develop into an effective strategy for freeze production.

Horticultural crops often are differentiated from agronomic crops by their high moisture content. Indeed, horticulture is fundamentally about water, and thus its availability and economics will in large part dictate the success of horticultural practices and industries. The determination of 
precise water needs for certain horticultural crops has been developed in an effort to conserve water and improve crop quality. Salinization has become a world problem, and the issues of water use and water quality clearly will be the focus of irrigation research in the next hundred years as agriculture is confronted with expanding industrial and urban demands.

Mechanical HaRvest. Mechanical harvest started with grain crops and soon expanded to horticultural crops, particularly root crops such as potato, sweetpotato, and onions, and later to peas and beans. English peas were harvested mechanically as early as 1930 (maybe even earlier). Mechanical harvesting of potato and sweetpotato began after World War II. However, it was difficult to mechanically harvest many fruit crops because of the problem of uneven ripening, selectivity, and bruising. A breakthrough was made in the 1950s with the development of the tomato harvester and it did not take long for the harvester to completely change the processing tomato industry. Mechanical harvesting was to completely change cultural practices and was accompanied by high plant populations, breeding for concentrated ripening, productivity, processing yield and quality, and the use of growth regulators to ripen fruit on schedule. Mechanical harvest of tomato had unintended consequences. The entire tomato paste industry moved to California. The industry continues to evolve, and at the present time it has moved from northern to southern California because the occasional rains during harvest caused quality problems. Mechanical harvest soon moved to fruit destined for processing, such as blueberry, raspberry, tart cherry, and grape. However, mechanical harvest has not become the norm for fruit destined for the fresh market because of bruising problems as well as social considerations to protect higher paying jobs for migrant laborers. In such cases, harvest has been accomplished by a combination of hand harvest and mechanical aids. The mechanical revolution also affected ordinary cultivation practices including transplanting, orchard establishment, and pruning.

Mechanization had a great impact on postharvest horticulture, as the backbreaking job of lugging crates was taken over by forklifts to move larger and larger pallets. The packing house underwent transformation as sorting and grading and packing were largely taken over by increasingly sophisticated, seemingly intelligent machines. Today, electronic color sorters have been employed in many ways in horticultural production, from fruit and vegetable processing of factory lines to seed-purity operations, although the human eye continues to find a place on the sorting line.

InSTRUMENTATION. In the last half of the 20th century, advances in instrumentation greatly affected horticultural research, especially in plant physiology and plant biochemistry. The tedious parts of chemical analysis such as the cumbersome Kjehldahl apparatus for nitrogen determination in soils and tissues developed into inductively coupled plasma (IPC) spectroscopy. Soil and foliar analysis were completely altered with sequential analysis using chromatographic techniques (first paper, then thin layer, and now gas chromatography combined with mass spectroscopy) that completely changed qualitative and quantitative analysis. Analytical procedures for complex secondary compounds in horticultural plants, such as vitamins and vitamin precursors, pigments, flavors, and defense compounds were developed using techniques such as gas chromatography and high-pressure liquid chromatography (HPLC). Modern instrumentation allows for temperature and light control and auto-sampling capability, thereby eliminating much of the tedium and time associated with the measurement of such compounds.

Instrumentation is particularly important in the area of photosynthesis research, where measurements of carbon fixation have changed dramatically during the 20th century. In the 1930s, plant physiologists recognized that carbon dioxide concentration was important for photosynthetic activity, although much of the work was conducted on individual leaves from plants growing in pots. Horticulturists became very interested in examining the impact of carbon dioxide concentration on photosynthesis of plants growing in horticultural production environments. The methods available at that time to evaluate the amount of atmospheric carbon dioxide included gasometric, volumetric, electrometric, and gravimetric techniques, none of which were very promising. The desire to understand the photosynthetic rate in a real horticultural environment led to the seminal work of Heinicke and Childers, reported in 1937 in Cornell University Experiment Station Memoir 201 (Faust, 1989). Their paper was a marvel of both endurance and scientific accomplishment. Childers measured the level of irradiation, leaf area, transpiration, and carbon assimilation for an entire season using an apple tree growing in a glass-enclosed box in an experimental apple orchard. This pioneering study led to evaluations of field-level photosynthetic rates in agronomic crops and to the design of field cages to evaluate photosynthesis in a range of other environments. Today, photosynthetic rates can be evaluated using highly sophisticated, portable, lightweight instrumentation developed for individual plant tissues, organs, or plants. The equipment can measure light interception, transpiration, photosynthetic efficiency, and a range of other parameters in an instant, thereby greatly improving the speed, accuracy, and efficiency of whole-plant and field level horticultural research.

The fields of genetics and molecular biology have perhaps seen the greatest benefits from the instrumentation revolution. The polymerase chain reaction (PCR), and the instrumentation designed to perform routine PCR amplification in a matter of hours has completely revolutionized genetic analysis in horticulture. By virtue of the fact that millions of copies of DNA fragments can be made in very short time periods, genes and DNA polymorphisms can be studied and used as diagnostic markers for a range of applications from genetic engineering to assessments of seed purity to characterizing phylogenetic relationships. The new chemicomechanical revolution reached unprecedented speed and accuracy in the field of genomics where nucleotide sequencing is performed at speeds unimaginable 10, much less 100 years ago, and a new phrase "high throughput" has been coined to describe the automated generation and collection of large amounts of data at very high speed.

Statistical analysis became an integral part of agricultural research in the first half of the 20th century. The monotonous and time-consuming job of data analysis was first carried out by hand, and then by handcranked, later electrified, calculators. In the last 30 years, computers and computer programs completely changed the way data are handled. Advances in numerical analysis turned out to be essential components of the genomic revolution.

The presentation of data underwent a remarkable transformation. Computer graphic technology for charts and graphs have made the LeRoy lettering sets as obsolete as the Keuffel and Esser slide rule. The scientific talk was transformed from excruciating, boring presentations where scientific papers were simply read (much as is inexplicably still the case in the humanities), to real theatre with improved visual-presentation techniques evolving from lantern slides, to overheads, the carousel slide projector, and, now, computer-generated PowerPoint presentations. Poster presentations, an innovation developed in the 1960 s, were modernized by advances in formatting software and large plotters.

\section{The Chemical Revolution}

Plant nutrition. Interest in substances that would increase crop growth date to antiquity and in fact Democratus of Abdera, an early Greek philosopher, proposed the strikingly modern concept that plants are derived from a combination of chemicals. Early Roman agricultural writers recognized the beneficial effects of animal manure, plant residues from leguminous crops, and crop rotation. Despite this knowledge, there was no real understanding of the theory of plant nutrition, and the contributions of organic matter and inorganic material were confused up to the 19th century. It remained for Justus von Liebig (1802-1873) to demonstrate that carbon was supplied by the air and not by humus, although he believed it was absorbed by roots. Liebig assumed that most $\mathrm{N}$ was absorbed from air but was unaware of $\mathrm{N}$ fixation by bacteria.

There was a strong sense among leaders of the U.S. that European scientific developments could play a role in our agricultural development, and nowhere was this sense stronger than in the political stronghold of the U.S., New England. The sad fact that rocky New England soils were nutrient-poor was, inadvertently, the impetus to search for scientific solutions to agricultural problems. In particular, a significant effort was made to find chemical solutions to agricultural production issues. This was particularly true during the 19th century, when agricultural chemistry was synonymous with agricultural science. The primary promise of agricultural chemistry was to improve agricultural productivity through soil fertility, and the place this was needed most was in the newly settled region of New England.

As agriculture in the U.S. began to develop during the late 18th century, farmers began to realize that the rocky soils in New England could benefit greatly from fertility amendments. The work of European soil chemists, in particular Justus von Liebig, was held in very high regard during this period. Methods were developed to analyze soil composition and recommend practices to improve their fertility. During this period, 
agricultural societies such as the Massachusetts Society for Promoting Agriculture (MSPA) began to encourage scientific practices in agriculture as well as stimulate research that would benefit farming (Anonymous, 1871). One of Liebig's students, Samuel Johnson, was responsible for starting the Connecticut Agricultural Experiment Station(CAES) in 1875, the first of its kind in the United States. State agricultural experiment stations would not be widely developed until the end of the 19th century, with the passage of the Hatch Act in 1887. The CAES had a focus on soil fertility and correct labeling of commercial fertilizers and was one of the first proponents of chemical research in agriculture in the U.S.

The contribution of plant nutrition as a science bloomed in the 20th century. Important advances in knowledge included the contribution of air as a source of carbon and nitrogen, the fixation of $\mathrm{NH}_{3}$ via the Haber process, the concept of cation exchange and soil fertility in promoting the development of the fertilizer industry, the concept of essential elements, importance of trace elements, respective roles of nitrate and ammonia nitrogen in plant nutrition, soil classification, recognition of the importance of soil tilth and $\mathrm{pH}$, the problems of nutrient balance, the role of calcium in fruit disorders, the use of foliar application, soil testing, and leaf analysis (Korcak,1992).

Advances in nutrition were involved in the development of synthetic soils, which led to container production of ornamentals, hydroponics, and tissue-culture technology. Out of these developments grew such innovations as plug technology, expansion of agriculture to sandy soils (Florida) and muck solids (Indiana, Michigan, and Wisconsin), and to micropropagation.

In the last quarter of the 20th century, concerns over the environment and the growth of the organic sustainable agriculture movement have led to reappraisal of plant nutrition with the realization that excess amounts of fertilizers could lead to environmental problems. Some questioned the sustainability of relying too heavily on inorganic nutrition. Yet, at the same time it has now been conclusively demonstrated that poor production in many parts of the tropical world is directly related to the fertility of problem soils and plant nutrition is once again becoming considered as a critical component of food production and the alleviation of world hunger and world poverty. The 2002 World Food Prize, announced at the 2002 International Horticultural Congress cohosted by ASHS was presented to Pedro Sanchez for his work in South American and Africa arising from his efforts at improving the productivity of tropical soils. In a lecture at the presentation, Dr. Sanchez developed the connection between horticulture and poverty reduction.

Pest control. The search for chemicals for pest control has an ancient tradition but the great variety of nostrums had little value. The first example of successful pest control occurred in the 19th century with the use of Bordeaux mixture (copper sulfate and lime), originally sprayed on grapes to discourage pilfering, when it was observed that it reduced several fungal diseases, particularly powdery mildew. In the early 20 th century this material was basically the only weapon to control many fungal diseases of crops (apple scab for instance), while a number of truly dangerous materials were used such as lead arsenic for codling moth control and mercury compounds for seed borne diseases.

The development of pesticides received a major boost during World War II with the discovery that DDT could control insects at very low concentrations. However, DDT, despite its positive insect-control effects, was easily concentrated in the food chain, and was found to adversely affect birds through a reduction in eggshell thickness. The publication of Silent Spring by Rachel Carson in 1962 initiated the environmental movement. Although the development of chemical pesticides led consumers to expect and demand blemish-free horticultural products, the indiscriminate use of pesticides was responsible for a backlash. This led to attempts to reduce the use of chemicals in agriculture and to strive for environmentally friendly pesticides and practices. As a sign of the times, Joni Mitchell sang in Big Yellow Taxi:

\section{Hey farmer farmer \\ Put away that DDT now \\ Give me spots on my apples \\ But leave me the birds and the bees, please!}

The reduction of pesticides by employing many avenues of control including chemical, biological, and cultural techniques is known as integrated pest management (IPM), and this is the current mantra of most horticultural scientists. Most horticulturists feel that while it is inconceivable that pesticides can be completely eliminated, it is clear that more environmentally friendly materials can be created, and that alternate technology can further reduce usage. It also is clear that horticultural marketers and, to some extent, consumers, are interested in crops produced with more environmentally friendly practices. The phenomenal growth of the organic food market in the U.S. and Europe, as well as the appearance of new eco-friendly brands of certain horticultural products will expand efforts designed to deliver horticultural products produced with lower amounts of synthetic pesticides and less impact on the environment. The ultimate control may be biological through gene action, but the technology of moving resistance genes into organisms also has become controversial, as discussed below.

Growth REGULATION. One of the main horticultural contributions in the 20th century was the regulation of plant growth by specific chemical substances (Looney, 1997). The seminal work in this field traces to a classic experiment on phototropism, the bending growth of plants toward light, carried out by Charles Darwin and his son, Francis. They were able to demonstrate in a simple but brilliant experiment involving oat seedlings and a razor blade that the ability of seedlings to respond to light was due to the tip of the plant. In 1880, a German physiologist named Julius Sachs introduced the concept of causality to organ development and assumed the existence of root-forming, flower-forming, and other substances that moved in different directions in the plant. In 1911 and 1913, Boysen-Jensen demonstrated by grafting that the phototropic stimulus was chemical in nature. The term hormone, introduced into animal physiology to denote a substance produced in one part of an organism and transferred to another part to influence a specific physiological process, was to be adopted as well by plant physiologists.

In 1928, Fritz W. Went demonstrated that a substance from the excised tip of the oat coleoptile (seedling shoot) could be absorbed by agar. Furthermore, the infused agar block when placed on the cut surface of the coleoptile produced the effect achieved by the excised tip alone. The active substance from the coleoptile tip was later shown to be indoleacetic acid (IAA) or auxin, the natural growth substance that affects cell elongation and other processes. In 1937, F.W. Went and K.V. Thimann of the Boyce Thompson Institute conclusively demonstrated that the hormone concept was applicable to plants, and the term phytohormone was coined. In their book, Hormones and Horticulture, Avery and Johnson (1947) confidently stated that "A chemical revolution is sweeping through the agricultural world. It is unrivalled by any of the previous great advances in agriculture and, perhaps, by most advances in the biological field. For the first time man can change the pattern of growth and development of plants; can retard growth here and speed it there. The growth-controlling hormones...now in use are but crude beginnings."

This was the first of many research bandwagons that were to sweep horticultural science, but the plant-growth-regulator bandwagon had staying power and was to have a profound effect on agriculture. The singular event was the development of 2,4-D, a chemical similar to auxin, whose development is described below. Herbicides have become essential to the modern production of agronomic and horticultural crops. The hoe, after 7000 years, finally was relegated to the home garden.

A number of scientific papers published during the 1940s indicated that certain plant-growth regulators could act as herbicides if used at toxic doses. One such class of promising compounds were phenoxy and benzoic acids, which had been discovered earlier by P.W. Zimmerman and A.E. Hitchcock. One of those compounds, 2,4-dichlorophenoxyacetic acid $(2,4-D)$, seemed to serve as a very promising selective herbicide, killing broadleaf weeds but not the grasses that grew alongside them. In addition, it was more than a thousand-fold more effective than other inorganic compounds. Classic work by P.C. Marth and J.W. Mitchell published in 1944 (Weller and Frank, 1989) described the value of this selective herbicide in crop production. This, in turn, opened a new avenue for controlling weeds in cereal and turf production, and today 2,4-D is still used widely in these applications. There were other dramatic economic effects of growth regulation, especially in horticulture. These include rooting initiation, flower induction, fruit setting and thinning, abscission control, growth inhibition, and fruit ripening accelerators and inhibitors.

The increased use of growth regulators and pesticides in general led to an outpouring of concern for the environment. This was the 
catalyst of the organic/sustainable agriculture movement which had its birth in elimination of inorganic fertilizers. The organic movement grew to become a philosophical reaction to technology, and strives to eliminate synthetic chemicals in agricultural production except those that are natural or organic. Thus, soil amendment with rock phosphate or lime was considered acceptable, whereas superphosphate was not. Similarly, pyrethrums, compounds from Chrysanthemum species, were acceptable, but not the modified compounds called pyrethrins. Spores of Bacillus thuringenis were acceptable, but the use of the gene encoding the toxin and introduced to the plant via transgene technology (genetic engineering) was considered an anathema. The organic concept found a willing advocate in the home gardener but had little effect on commercial agriculture until recently.

The organic/sustainable agriculture movement is now causing a fundamental change in the attitude of growers and consumers alike. It has increased awareness of the possibility of a more ecological approach to agriculture but is up against the need to increase production of food in the developing world. The developed world, as a result of the advances in scientific agriculture, is awash with surpluses. In fact, the major problem for European and North American agriculture has been the ruinous prices to growers due to overproduction and the cost to taxpayers of subsidies that can account for almost half of agricultural receipts. However, in the developing world, food prices still account for a large percentage of family expenditures. The larger problem at issue is the interrelationship of biological systems and the prospects for sustained agricultural productivity. One of the unforeseen benefits of the sustainable agricultural movement has been to raise awareness of crop production among the general public. And, in some cases, this has heightened the level of public discourse and debate on matters concerning the environment and the future of food. The challenge to horticultural science will be to steer a course between the Scylla of environmental chaos and the Charybdis of world hunger.

\section{The Biological Revolution}

The biological revolution emerged from the work of Charles Darwin and Gregor Mendel both horticultural scientists in their own right. Darwin was to investigate the myriad changes introduced by horticulturists in selecting garden plants which led him to formulate his theory of evolution, a theory that was to unify biology and shock the world. His work on plant movements were to presage the beginnings of phytohormones. Gregor Mendel was a cleric from Brunn, who unraveled the laws of inheritance from studies of the garden pea and in a sense created the science of genetics. The same decade that Mendel reported on his famous work on inheritance in the garden pea (1865), Johann Fredrich Miescher described a substance called nuclein derived from pus that was extracted from surgical bandages and later found in fish sperm. Nuclein was later shown to consist of protein and nucleic acids. The research of Mendel and Miescher was the origin of investigations that that would culminate in the unraveling of the genetic code in the 20th century.

INHERITANCE. The similarities and dissimilarities between parents and offspring have been commented on from the beginning of the written record. The aphorism "like begets like" is the basis of genetic wisdom. Knowledge of the genetic connection between parents and offspring is implicit in biblical prohibitions of adultery, which results in ambiguity regarding inheritance and paternity. Similarly, insight into the function of sex in plants dates to Mesopotamia with clear knowledge of pollination in date palms to achieve fruit set. Theophrastus was aware of these ancient concepts, but this information became virtually lost until the Dutch botanist JacobCamerarius (1670) experimentally proved the sexual nature of plants. Despite the clear relation between parent and offspring there was not a basic way to predict performance. Hereditary theories were murky and the best analysis was a blending of blood although it was understood that some characters could reappear and that certain traits could be sought and maintained in certain lineages.

In the 19th century, the first experimental research began to confront the problem of inheritance. Thomas Andrew Knight demonstrated segregation of seed characters of the garden pea but offered no explanation. Charles Darwin was the first to demonstrate and explain a mechanism of evolution that could account for the highly branched lineages that nature represents. He called this mechanism natural selection. Darwin collected a vast amount of information and carried out a review of experimental studies but failed to arrive at a satisfactory theory of inheritance. His concept of pangenesis involved a persistent hereditary unit, but he assumed incorrectly that units were replenished by input (gummulea) from somatic tissue. The difficulties of a genetic theory were compounded by a lack of understanding of variation both continuous and discontinuous, interaction with environment, and of complications introduced by dominance, inbreeding, outbreeding, apomixis, and mutation. Despite his inability to account for the mechanism of inheritance, Darwin's view on evolution was to become the unifying, dominant force of biology in the 20th century.

Yet all confusion was at first unknowingly swept away by the obscure monk, Gregor Mendel, in a provincial town of the Austro-Hungarian Empire. In a series of brilliant experiments with the garden pea, Mendel was able to perform precisely the correct experiment with precisely the correct interpretation. His evidence was presented in a scientific paper that is a model of order and lucidity (Janick, 1989b). More astonishing, the hypothesis was formulated in a pre-cytological era. Mendel essentially demonstrated that characters were controlled by entities or factors that we now call genes. These genes interact to form a phenotype and segregate unaltered from one generation to the next. He demonstrated that in peas, two forms of the gene (we now call them alleles) can interact in the formation of a visible trait (phenotype). When the alleles vary in function, one could dominate the other. Furthermore, the recessive allele although hidden, passes unaltered from generation to generation, and reappears in predictable phenotypic ratios.

GENETICS. The immediate impact of Mendel's paper, presented in 1866, was nil. It was fairly widely distributed but either ignored or brushed off until its rediscovery in 1900 . Yet the period from 1866 to 1900 , the classical period of cytology, the study of cells, was to establish the basic part of structural cell biology that put Mendel's theoretical discovery of inferred genes (anlage) into structures contained in each living cell. In 1866, Ernst Haeckel published his conclusion that the cell nucleus was responsible for heredity. Soon thereafter, the chromosomes, the physical framework for inheritance, became the focus of attention in mitosis, meiosis, and fertilization with speculation on their relation to heredity. The issue was cloudy because the details of the meiotic process were not well understood.

The pieces of the puzzle however quickly fit together only after the independent verification of Mendel's result by Hugo de Vries, Carl Correns (a student of Nägli, the professor who was sent Mendel's paper but refused to understand it), and Erich von Tschermak. Neither one of them completely understood Mendel's paper although Correns came close. It remained for W.S. Sutton to recognize, in a 1902 paper, that the association of paternal and maternal chromosomes in pairs and their subsequent separation during meiosis constituted the physical basis of Mendelian genetics. Sutton wrote two of the most important papers in cytology but never received his $\mathrm{PhD}$; he left science for surgery. Sutton was a student of E.B. Wilson who described the behavior of chromosomes and speculated on their role in heredity in his famous 1896 work, The Cell.

The genetic revolution had a rapid impact on plant and animal improvement. Although breeders had unconsciously been using many appropriate procedures via crossing and selection in the 19th century, the emerging science of genetics and, especially, the fusion of Mendelism and quantitative genetics, put plant and animal breeding on a firm theoretical basis in the 20th century.

The relation between genetics and post-Mendelian plant breeding is best exemplified by two routine breeding protocols. One is the extraction and recombination of inbreds combined with selection to produce heterozygous but homogeneous hybrids, a procedure analogous to reforming Rubic's cube, whereby combinations are first disturbed to complete the final order. The other is backcross breeding, in which individual genes can be extracted and inserted with precision and predictability into new genetic backgrounds. The combination of backcross breeding to improve inbreds and hybrid breeding to capture heterosis is the basis of the present day strategy known as the inbred-hybrid method. The elucidation of the genetics of male sterility in onions by horticulturists H.A. Jones and A.E. Clarke solved a horticultural problem of hybrid seed production and brought attention to non-nuclear genetic factors (Gabelman, 1989).

The success of the new science of plant breeding had a substantial impact on agriculture and horticulture. Dramatic successes quickly followed: examples include hybrids and disease-resistant crops. A spectacular example of plant breeding prowess was the development of 
short-stemmed, photoperiod-insensitive wheat and rice, the forerunners of the Green Revolution for which Norman Borlaug, a plant breeder with the Center for the Improvement of Maize and Wheat (CIMMYT), was to receive the Nobel Prize for Peace in 1970. Other advances include the creation of a new crop species, triticale, from hybrids of wheat and rye (an accomplishment in which Borlaug also played a part), a host of disease-resistant crops, as well as triploid seedless watermelon developed by H. Kihara, produced from intercrossing tetraploids (plants having twice the number of chromosomes) and diploids (Eigsti, 1989).

Of particular significance in the history of horticulture is the understanding that genetics can control disease reaction in plants and that host-plant resistance can be an object of selection. Beginning with L.R. Jones in the early part of the 20th century, research in horticulture and the newly developing field of plant pathology led to the idea that breeding could be used to develop disease-resistant cabbage. This work was picked up by J.C. Walker, who used experiments in controlled-temperature tanks to demonstrate the genetic control of resistance to cabbage yellows, the first such demonstration for a plant disease (Coyne, 1989). This ushered in an era of breeding for disease resistance in many agricultural species.

The progress attributed to the scientific approach to agriculture can be shown by the dramatic increases in average yield in the U.S. from the 1940s to the present: 6-fold for processing tomato, 5-fold for potato, and 4-fold for maize (Warren, 1998). In the case of tomato, the improvements were due to a combination of genetic and cultural factors; in the case of the potato, higher yields were due mainly to superior management practices such as nitrogen fertilization, which became widespread in potato production in the 1940s. Interestingly, a substantial portion of U.S. potato production remains dependent on a single cultivar, 'Russet Burbank'. There was a doubling of yield for onion beginning in the 1920s, table beet and snap bean in the 1930s, and carrot beginning in 1950s (Tiefenthaler et al., 2003). Part of the reason for the large difference between yield gains in most vegetable crops vs. maize is because vegetable breeders must simultaneously select for many characteristics, such as flavor, color, shape, and texture of high-moisture, immature organs, a challenging and daunting task.

Horticultural crop breeders succeeded in making great improvements in quality factors during the 20th century in both ornamental and edible crops. The startling array of colors, shapes, and forms currently available in many ornamental species represents the tremendous success of both the hobbyist-breeder and the professional geneticist. The use of related species to improve the visual, adaptive, and pest-resistant qualities of ornamental species serves as an outstanding example of the utilization of plant genetic resources. Tremendous improvements in nutritional quality have been achieved by vegetable crop breeders, including enhancing the pro-Vitamin A value of carrots and the modification of carotenoid profiles in a variety of species including tomato and many cultivated members of the Cucurbitaceae. Because horticulturists are often experts in the domain of plant-human interaction, they have chosen to play a critical role in the development of unique pigments, flavors, and nutritionally relevant secondary compounds in ornamental and edible crops. This area of horticultural science will likely expand significantly during the $21 \mathrm{st}$ century as knowledge of the specific health contributions of horticultural crops emerges and astute consumers exert demand for unique horticultural products. Many of the efforts described above involve the manipulation of secondary metabolites through physiological genetic strategies. These projects represent some of the most unique and promising areas of horticultural research today. For example, genetic approaches to reducing antinutritional factors such as oxalic and phytic acid, or manipulating mineral uptake mechanisms to enhance phytoremediation efforts may lead to new horticultural crops and industries, in addition to improving human and environmental health.

BIOTECHNOLOGY. Dramatic advances in biology augur a third agricultural revolution involving biotechnology, a catch-all term that includes both cell and DNA manipulation. A conventional baseline for the biotechnological revolution is 1953, the date of the brilliant Watson-Crick paper on the structure of DNA and exactly 50 years after the founding of ASHS. However, the biotechnological revolution has no precise beginning, because science is cumulative. One pathway developed from a series of investigations into gene function and structure and another from the culture and physiology of cells using microbial techniques.

One of the most powerful engines driving basic research in plant biology is the ability to target particular genes and gene products in key biochemical pathways and modify them using the tools of molecular biology. Photosynthesis research, for example, has benefited tremendously from the cloning and sequencing of genes coding for key proteins in the photosynthetic machinery. Cloned genes are also used to develop mutants that are deficient in particular pieces or subunits of the protein, and whose function can be restored following transformation with complementary pieces of DNA. Horticulturists have played a part in the biotechnological revolution. The gene gun, an innovative way to introduce genes, was developed by J.C. Sanford, a small-fruit breeder at Cornell University, Geneva.

In another corner of biology, plant and animal physiologists far removed from genetics were attempting to culture cells and tissues in a fully defined medium. Pioneering studies of in vitro culture of plant organs and tissues were performed by G. Haberlandt in 1902 who predicted that the notion of producing plants from cultured cells would provide final confirmation of the cell theory (see Janick, 1989a). There was slow but continuous progress. In 1922, procedures were introduced by W.J. Robbins for the culture of roots and in $1922 \mathrm{~L}$. Knudson developed the aseptic germination of the embryo-like seed of orchids (Arditti, 1989). The breakthrough in plant cell and tissue culture arose from a series of physiological investigations, principally by Folke Skoog and his coworkers, on growth-regulating substances, including vitamins, hormones (particularly auxin and cytokinins), and organic complexes such as liquid coconut endosperm, and from the development of generalized tissue-culture media by P.R. White in the 1930s and 1940s, and most successfully by horticulturist Toshio Murashige and Folke Skoog in 1962. The demonstration of asexual embryos initiated in the cultures of carrot root cells in 1958 by J. Reinert and by F.C. Steward and K. Mears (an event analogous to producing human babies from skin cells) was a confirmation of the concept of cell totipotency: that each living cell contained all the genetic information.

Plant cell and tissue culture was quickly used in horticulture for rapid propagation, first for orchids by G.M. Morel in 1960 and then for a number of ornamental plants. Extensive investigation continues to explore the potential of cell and tissue culture as an adjunct to crop improvement. Techniques include embryo rescue, freeing plants from virus and other pathogens, haploid induction, cryogenic storage of cells and meristems for germplasm preservation, the creation of new nuclear and cytoplasmic hybrids via protoplast fusion, and the exploitation of changes, dubbed somaclonal variation, induced by cell and tissue culture. Cell and tissue culture was an essential element of the DNA technology for production of transgenic plants.

Recombinant DNA technology has raised great expectations for agriculture. The discovery of enzymes that cleave DNA at specific sequences and subsequently ligate to extrachromosomal DNAs of bacteria permit gene replication in a bacterial host, a process known as gene cloning. The production of human insulin by bacteria, the first commercial achievement of gene cloning, stimulated a new industry for producing gene products for therapeutic uses such as blood-clotting factors and growth hormones. The technology to describe cloned genes in terms of nucleotide sequence is available and thus manufactured genes are theoretically feasible. Finally, DNA can be inserted into the DNA of higher plants by various techniques including the gene gun. The most promising vector for dicotyledonous plants, but now also used for monocots, has been the tumor-inducing plasmid of Agrobacterium turnefaciens, a bacterium that normally incorporates its DNA in the host as part of the infection process. Even transgenic technology is not new!

The story beyond this point although spectacular in terms of scientific achievement is still somewhat speculative because agriculturally useful genes are not in surplus and their expression within foreign genomes is still completely unresolved. The ability to move new genes into old plants has led to imaginative flights of fancy: a new range of disease-and stress-resistant plants, nitrogen fixation by non-legumes, and amino-acidbalanced plant protein. As a result, much venture capital has been absorbed by aspiring firms, large and small. However, the concept of improving agriculture in the traditional sense by recombinantDNA technology became a reality with three dramatic discoveries: the creation of a slow-ripening tomato, 'Flavr Savr', the production of glyphosate-resistant soybeans, and the development of pest-resistant maize and cotton by insertion of the insecticidal gene Bt, from the bacterium Bacillus thuringesis. 
The slow-ripening tomato was considered a scientific success but not a commercial one for a number of interesting reasons. The lessons from this story bear retelling, because ironically it was horticultural barriers themselves (and the failure to appreciate their importance) that limited the success of this unique product.

The 'Flavr Savr' was developed by scientists at a California company known as Calgene, an upstart in the rapidly expanding world of plant biotechnology in the early 1980s. Calgene had significant financial support from Procter and Gamble and held a number of patents on herbicideresistant plants. Calgene's idea, to use a transgenic approach to limit the activity of the enzyme polygalacturonase (PG) and thereby inhibit tomato ripening, was visionary for the time. By introducing the sequence of PG in a reverse orientation, company scientists were successful in shutting down the activity of this enzyme and thus tomato fruit stayed red for many weeks without shriveling or rotting. Of course, this was a signal to many that fruit could be harvested ripe instead of green, and transported to grocery stores where consumers could actually purchase ripe, good-tasting tomatoes in winter. Investors voted with their wallets on Calgene's idea, and soon the company was spending millions of dollars to market the 'Flavr Savr' tomato to the general public.

Calgene pushed for regulatory approval of its 'Flavr Savr' tomato through the Food and Drug Administration (FDA), to prove to consumers that the tomato was safe to eat. This effort took considerable time and money in the form of animal testing and political wrangling, but in the end the FDA did rule that the 'Flavr Savr' was not significantly different than any other tomato on the market. Thus, the first genetically engineered food product available anywhere in the world became a classic horticultural product modified to improve consumer food angst. Unlike many of today's successful transgenic crops, 'Flavr Savr' was a horticultural product developed to appeal directly to the consumer, rather than the farmer. Many have speculated whether transgenic technologies would have fared better in today's marketplace had the 'Flavr Savr' been successful. This is because consumers clearly could see benefit to an improved tomato, whereas the potential ecological benefits of herbicide resistant corn and soybeans may not be as widely appreciated by the nonfarming public.

Despite all of this promise, the 'Flavr Savr' tomato failed. Unfortunately, Calgene underestimated the importance of horticultural science to modern plant biotechnology. Even though the 'Flavr Savr' actually did what they said it did, Calgene had only introgressed the antisense PG construct into a single tomato cultivar, one that would not be able to grow well in the wide array of environments necessary for consistent tomato production year-round in and around the U.S. In addition, they failed to appreciate the complexity of the postharvest environment: shipping ripe tomatoes was significantly more challenging than shipping unripe, green tomatoes across the country in the middle of winter. Calgene was confronted with problems familiar to many horticultural scientists, but was unable to solve them in time to be successful in the marketplace. In short, the product was a success with consumers who bought it even at significantly higher prices than conventional tomatoes, but production costs and problems killed Calgene. Writing in Lords of the Harvest, Dan Charles (2001) quotes produce magnate Bob Meyer on the horticultural issues surrounding the 'Flavr Savr':

"They were doing their genetic engineering. They were all PhDs But put a molecular biologist out on a farm, and he'd starve to death. They had no concept of what agriculture was like. There was no one like myself. I'm the bottom of the bucket, you might say. I'm a dirt farmer. I'm the guy that puts the plant in and gets the fruit out and gets it shipped.

They thought it was simple. You get a tomato plant and plant the damn thing. But you don't just get a seed and plant it. I work in the Salinas Valley, and that requires two different varieties as the weather changes; and the San Joaquin Valley, that requires two or three different varieties. At the southern end we have lots of sun; we need lots of leaves, and where we have rain we need a plant that doesn't have so many leaves, so the rain won't destroy it.

They had no concept of how many varieties it would take. They said: 'So you mean we'll have to put this gene in more than one variety?' So I actually gave them a list of all the tomato varieties that I thought we should use, in the United States and Mexico. And it was a large list. They were....surprised. I was going to use another word. I'll be nice and say surprised."
Once developed, adoption of "Roundup-Ready" soybeans was extremely rapid, unsurpassed in agriculture. $B t$ cotton also was rapidly adopted and $B t$ maize somewhat less because the cost-benefit ratio was not as high as the economic impact of European corn borer varied with location. By 2002, herbicide-resistant soybean accounted for $75 \%$ of the crop area, $B t$ and herbicide-resistant cotton $71 \%$, and $B t$ maize $22 \%$ in the U.S. Yet a number of widely predicted changes, such as the creation of blue roses, has not occurred. The reasons progress has been slower than expected were perhaps too much early hype, which created unrealistic expectations; a lack of appreciation for the complexities involved, such as the need for specific promoters; a paucity of really useful genes; technical difficulties of gene transformation; and patent problems. However, the greatest roadblock was fear by the consumer, a backlash encouraged by a new class of reforming Luddites, as they were derisively termed by the technocrats, after a band of workmen who in 1811-1816 prevented laborsaving machines in the looming industries of England. Fear of genetic manipulation emerged and restrictions imposed on research may slow advances by reducing commercial interest. Consumer resistance in Europe was intense where transgenic crops have been termed Frankenfoods by their detractors, and production is essentially banned. The difference in attitude toward transgenic crops in Europe and America is due in some part to the loss of confidence by Europeans in their regulatory agencies which failed them in the Thalidomide disaster and the outbreak of madcow disease. The short-term future of genetically modified (GM) foods is cloudy, but the long-term future is positive. GM food is unlikely to be a problem in Asia in view of the high need for increased production and acceptance of biotechnology by China and several countries in South America, including Argentina and Brazil.

Despite the current backlash, tremendous advances in biotechnology continue to sweep the biological sciences involving 1) mapping and sequencing of the genomes (the complete set of genetic information on the chromosomes), 2) determining gene function, and 3) developing an understanding of DNA sequence homology among divergent genes in both related and disparate organisms. The term genomics, was coined for this technology. By 2001, the DNA of a few organisms had been completely mapped including bacteriophage, bacteria, yeast, nematode, Arabidopsis (mouse-eared cress), a rapid-cycling miniature plant of the mustard family, and finally, humans! Analysis of gene function indicates that all living organisms hold genes in common, and Darwin's principle of common ancestry was vindicated. Soon the genes of all our major crop plants will be mapped and sequenced. The names of the next emerging fields have already been coined: proteomics, which will unravel the protein changes involved with gene function and development; and metabolomics which addresses qualitative and quantitative aspects of metabolites. We live in very exciting times.

\section{Horticulture in the New Millennium}

One hundred years after the founding of ASHS we find horticultural production industries still organized by crop-production groups: fruit, vegetables, floriculture, ornamental horticulture, herbs, medicinal, and spices. However, increased sophistication of production resulting in enormous increases in yield and efficiency has reduced the number of growers, farms have become larger, and in some cases enormous. California and Florida have become the major horticultural states for fruit and vegetable production, but with globalization, horticultural imports are becoming increasingly important. Our technology has moved rapidly to Central America for floricultural products, and our greenhouse industry has suffered. Southern hemisphere imports of fruit and vegetables have had dramatic effects on our industries. Indeed, horticulture is in a constant state of change.

Postharvest horticulture has become increasingly important, as horticultural products are shipped from coast to coast and continent to continent. Our dining habits have altered such that half our meals are consumed away from home, and the consumption of ready-made meals and readymade dishes has increased dramatically. Advances in food technology have increased the consumption of packaged, fresh-cut vegetables and fruit, and processed food. In some cases, the increased ethnic diversity in the U.S. population has resulted in new crop introductions and new opportunities for horticulture. The rediscovery that increased consumption of horticultural products such as fruit and vegetables can reduce disease risk is regularly emphasized in the popular media. However, with the ar- 
rival of the field of food functionality, exaggerated and untested benefits have been ascribed to many natural products. While scientists strive to sort out conflicting claims regarding the medicinal value of horticultural products, the consuming public is naturally confused about the value of their food choices. Despite the facts that a number of fruit and vegetable crops were domesticated with medicinal benefits in mind, and that their consumption reduces the chance of disease onset, it is unlikely that any of these products can live up to the snake-oil-like claims that modern marketers suggest. In the end, dietary diversity, regular physical activity, and weight control will be more important goals than any one particular food source for the maintenance of good health.

Many forces have influenced the changes that have occurred. Horticultural science has expanded to the private sector and now that arena is responsible for more than $50 \%$ of research expenditures. However, it is fair to say that horticultural science and horticultural progress still remain centered within our universities, where the next generation of practitioners is trained, and where progress is archived in the publica- tions of our scientific societies. ASHS continues to play a role but this role is changing as our Society is changing. Throughout this period we follow the beat of different drummers. Consider the buzzwords that have affected us in the last 100 years: plant breeding, colchicine, cyrobiology, statistics, international programs, biotechnology, energy efficiency, genomics, organic agriculture, sustainability, integrated pest management and so forth. Despite these changes of focus, horticulture continues to provide food for body and soul, to enrich the lives of all, and to glorify the human condition. We here today certainly can agree that our lives depend on horticulture.

\section{YEARS OF ASHS}

A diverse and hardy band of American and Canadian horticulturists under the urgings of Spencer Ambrose Beach were informed in a circular dated 20 June 1903 (see Box below) that a horticultural society was needed because it "could be made the rallying point for horticultural

THE ORIGINATION OF THE SOCIETY FOR HORTICULTURAL SCIENCE

The first step toward the organization of the Society for Horticultural Science was taken by issuing the following circular letter

Geneva, N.Y., June 30, 1903

Dear Sir:

It is proposed that there be organized a society for horticultural science, the object of which should be more fully to establish horticulture on a scientific basis. The membership would naturally be made up of the horticulturists of the experiment stations and of the U.S. Department of Agriculture, together with other scientists whose work has a horticultural bearing. The meetings would be held in connection with those of some kindred society, as the American Pomological Society or the American Association for the Advancement of Science.

The amount of scientific work being done in this country along horticultural lines is not fully appreciated in the scientific world because in many cases it is obscured in presentation by a large admixture of popular features. In order to put this scientific work in the right light before the world it must be freed from all distracting elements. Scientific features should be brought prominently into the foreground and attention focused upon them. The scrutiny to which they would be subjected in this event would doubtless lead to a more complete investigation of some scientific points now imperfectly developed. In bringing about these results a society for horticultural science would be a potent factor.

Further, there is a large amount of general scientific work, especially in plant physiology and physiological chemistry, which has a direct and important horticultural bearing which is not making the impress on horticultural investigation that it should. This work should be reviewed from the standpoint of the horticulturist and its horticultural applications should be clearly pointed out. This service also the society for horticultural science could perform. Such a society could be made a rallying point for horticultural investigators, crystallizing about itself the scientific horticultural thought of the country.

One large result of the organization of this society would be the opportunity that it would afford for the differentation of scientific and technical from popular features in the presentation of results. The scientific and technical framework of investigation could be presented before the society in the form of memoirs and be discussed in the technical language of the laboratory. At the same time the popular presentation could be rid of all those undesirable technical features which under the present system are sometimes included, not for the benefit of the practical man, but simply for other investigators. This separate presentation of scientific features would emphasize their importance and tend to stimulate activity in further scientific investigation. That such stimulation is needed our station horticulturists are unanimously agreed. The creation of a society for horticultural science would be a logical and concrete expression of this need.

This society would not supplant any existing horticultural activities but would supplement all of them. It would aim to do for horticulture in general what the Plant Breeding Conference did for one special branch - it would call forth and centralize the most advanced horticultural thought of the day. It would be a Plant Breeding Conference generalized.

In submitting this proposition to you I feel assured beforehand of your sympathy with the general project. Can you not also give it your cordial co-operation and moral support? I should be glad to hear in detail your idea as to the organization and aims of the society. Especially I would be glad to have you drop me a line promptly, letting me know of your attitude toward the project and whether you will be at the meeting of the American Pomological Society in Boston, Sept. $10-12$ next.

If a sufficient number of favorable replies are received it is proposed to hold the first meeting in connection with the meeting of the American Pomological Society. If it is decided to organize all who shall have signified their favorable attitude toward the project will be notified at once and every effort will be put forth to have a worthy program prepared for the occasion. The expense connected with the society will be only nominal.

It will be an aim to have the proposed meetings enjoyable socially as well as profitable professionally.

Yours for the advancement of horticultural science,

S.A. Beach

The above letter was sent to the official horticulturists of the Agricultural Colleges and Experiment Stations of the U.S. and Canada, of the U.S. Department of Agriculture and of the Central Experimental Farm of Canada. It was also addressed to various botanists and other scientists. The proposal stated in the letter met with so encouraging a response that a second circular letter was issued, the text of which appears below.

Geneva, N.Y., Aug. 7, 1903.

Dear Sir:

The organization of the Society for Horticultural Science proposed in my circular letter of June 30 has been decided on. The proposition met with a wide and enthusiastic and almost unimously favorable reception among not only horticulturists but also a considerable number of botanists and other scientists. The need of the society is keenly felt and the time appears ripe for inaugurating the new movement. An attendance of at least thirty of those interested is assured for the Boston meeting and Professor L.H. Bailey has consented to preside at the first meeting.

The circular letter has elicited various and often divergent expressions of opinion as to the organization, affiliation and policy of the society, especially as to its affiliation. In order that the whole subject may be gone over thoroughly and deliberately a preliminary meeting for organization and conference will be held in the rooms of the Massachusetts Horticultural Society Wednesday afternoon, September 9, at two o'clock. It is hoped to have the fullest possible attendance at this meeting. The headquarters of the Society will be the same as those of the American Pomological Society.

On account of the time that will be required to discuss matters of organization it will be impracticable to present a scientific program.

Very sincerely yours,

S.A. Beach

HorTSCIENCE, Vol. 38(5), August 2003 


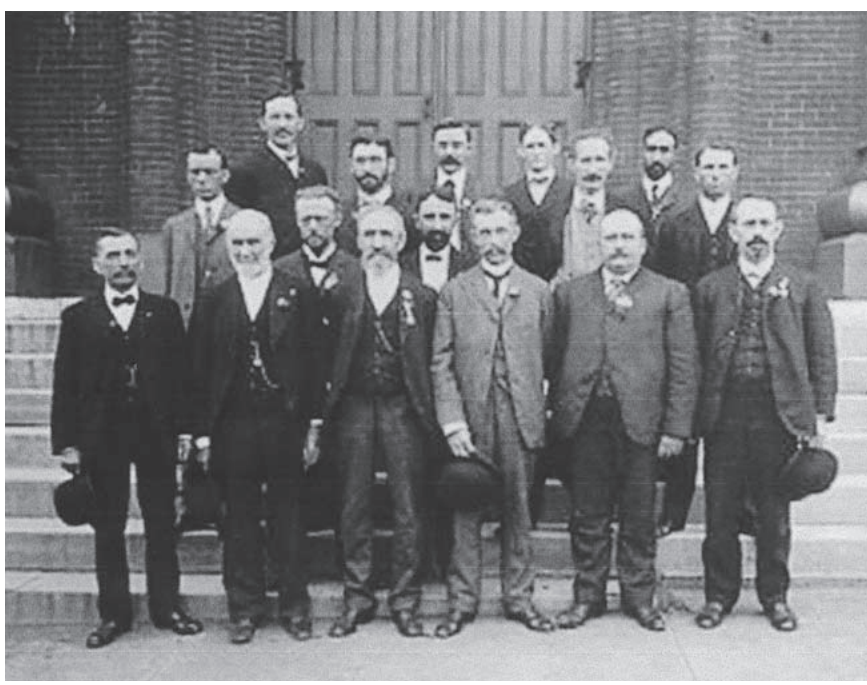

Fig. 1. Horticulturists attending the first annual meeting of ASHS in St. Louis, Mo. during a visit to the Missouri Botanical Garden, 28 and 29 Dec. 1903. Front row, left to right: 1) W.R. Lazenby. Ohio State Univ, Columbus; 2) William Henry Ragan, USDA, Washington, D.C (one of founders of Indiana Horticultural Society; 3) G.B. Brackett, USDA, Washington D.C.; 4) Spencer A. Beach, Experiment Station, Geneva, N.Y. (President 1911); 5) Levi R. Taft, Michigan State College, East Lansing; 6) Samuel B. Green Experiment Station, St. Anthony Park, Minn. Second row: 1) N.E. Hansen, Experiment Station, Brookings, S.D.; 2) H.C. Irish, Missouri Botanic Garden, St. Louis Third row: 1) Arthur T. Erwin, Iowa State College, Ames (President 1930); 2) R.A. Emerson, Experiment Station, Lincoln, Nebraska. 3) John Craig, Cornell College of Agriculture, Ithaca, N.Y. 4) unknown. Back row: 1) R.S. Mackintosh, Experiment Station, Auburn, Alabama; 2) Harold H. Hutt, Experiment Station, Logan, Utah; 3) E.E. Little, Iowa State College, Ames; 4) Fabian Garcia, New Mexico State College, Las Cruces.

investigators, crystallizing about itself the scientific horticultural thought of the country." This circular galvanized action, and a second circular letter was sent on 7 Aug. An organizational meeting held 9 and 10 Sept. in Boston's Horticulture Hall gave birth to the Society for Horticultural Science (changed to the American Society for Horticultural Science in 1916). Liberty Hyde Bailey, the most prominent horticulturist of his time, and indeed of the 20th century, was chosen as its first president. The rest is history.

On 28 and 29 Dec. 1903, only 6 months after the original circular, the first meeting was held at Central High School in St. Louis in conjunction with the American Association for the Advancement of Science (AAAS) (Fig. 1). Annual dues were \$2.; no dues were collected in 1908 and dues reduced to $\$ 1$ in 1912 . (The 100 year history of ASHS dues is included in Fig. 5.) Income for the first year was $\$ 94.10$ and expenses were $\$ 55.06$, producing a tidy surplus of $\$ 38.94$. The combined 1903-1904 membership role (Table 1) included 53 members from 27 states, one Canadian (W.T. Macoun) plus three honorary members: Ed Andre (France), Maxwell T. Martin (England), and James Wilson (U.S. Secretary of Agriculture). We have been an international society from the beginning. ASHS's first female member was Miss Fanny R. Wilkinson, Horticulture College, Swanley, Kent, England, listed as one of five foreign members in 1905.

\section{The Philosophy of Horticultural Science}

The title of Liberty Hyde Bailey's presidential address at the 2nd Annual Meeting of the Society for Horticultural Science in Philadelphia in 1904 (he could not attend the 1st meeting) asked a question that is still on the minds of many people: What is horticulture? To Bailey, the professional side of horticulture, defined by teaching and research, began in about 1874 with the work of W.R. Lazenby at Cornell University. The New York State Experiment Station at Geneva was the first to hire a horticulturist, Emmett S. Goff, who went on to found a department of Horticulture at the University of Wisconsin in 1889.

Bailey's vision of horticulture as a professional endeavor was pioneering for the time, and is relevant for today. He saw the scientific work of the horticulturist in very broad terms, and did not see how it was valuable to split basic and applied work. In his presidential address, Bailey com-

Table 1. Members of the Society for Horticultural Science, 1903-1904.

Bailey, L.H.

Beach, S.A.

Blair, J.C.

Brackett, G.B

Burnette, F.H

Butz, G.C.

Clark, V.A

Close, C.P.

Corbett, L.C.

Craig, J.

Davis, V.H.

Dickens, A.

Emerson, R.A

Erwin, A.T.

Ferguson, A.M.

Fletcher, S.W.

Galloway, B.T

Green, W.J.

Green, S.B.

Green, E.C.

Halstead, B.D.

Hansen, N.E

Hays, W.M.

Hedrick, U.P.

Howard, W.L.

Hume, H.H.

Hutt, H.H.

Irish, H.C.

Judson, L.B.

Lazenby, W.R.

Macoun, W.T.

Morris, O.M.

Munson, O.M

Orton, W.A.

Paddock, W.

Powell, G.H

Price, H.L.

Rehder, A.

Rolfs, P.H

Stinson, J.T.

Stuart, W.M

Smith, C.B.

Taylor, W.A.

Taylor, F.W.

Tracey, W.W.

Troop, James

VanDeman, H.E.

Walker, Ernest

Watson, B.M.

Waugh, F.A.

Weed, H.E.

Webber, H.J.

Whitten, J.C.

Cornell College of Agriculture, Ithaca, N.Y.

Experimental Station, Geneva, N.Y.

Experimental Station, Urbana, Ill.

Dept. of Agriculture, Washington, D.C.

Experimental Station, Baton Rouge, La.

Experimental Station, State College, $\mathrm{Pa}$.

Experimental Station, Geneva, N.Y.

Experimental Station, Newark, Del.

U.S. Dept. of Agriculture, Washington, D.C

Cornell College of Agriculture, Ithaca, N.Y.

University of Ohio, Columbus, Ohio

Experimental Station, Manhattan, Kan.

Experimental Station, Lincoln, Nebr.

Experimental Station, Ames, Iowa State University, Austin, Texas

Cornell College of Agriculture, Ithaca, N.Y.

U.S. Dept. Agriculture, Washington, D.C.

Experimental Station, Wooster, Ohio

Experimental Station, St. Anthony Park, Minn.

Experimental Station, College Station, Texas

Experimental Station, New Brunswick, N.J.

Experimental Station, Brookings, S.D.

Experimental Station, St. Anthony Park, Minn. Agricultural College, Mich.

Experimental Station, Columbia, Mo.

Experimental Station, Raleigh, N.C.

Experimental Station, Logan, Utah

Missouri Botanical Garden, St. Louis, Mo.

Experimental Station, Moscow, Idaho

University of Ohio, Columbus, Ohio

Experimental Farm, Ottawa, Canada

Experimental Station, Stillwater, Okla.

Experimental Station, Orono, Maine

U.S. Dept. Agriculture, Washington, D.C.

Experimental Station, Fort Collins, Colo.

U.S. Dept. Agriculture, Washington, D.C.

Experimental Station, Blacksburg, Va.

Arnold Arboretum, Jamaica Plain, Mass.

U.S. Dept. Agriculture, Washington, D.C. and Miami, Fla. Dept. of Horticulture, La. Purchase Exposition, St. Louis, Mo.

Experimental Station, Burlington, Vt.

U.S. Dept. Agriculture, Washington, D.C.

U.S. Dept. Agriculture, Washington, D.C.

Dept. of Horticulture, La. Purchase Exposition, St. Louis, Mo.

U.S. Dept. Agriculture, Washington, D.C.

Experimental Station, Lafayette, Ind. Washington, D.C

Experimental Station, Fayetteville, Ark. Bussey Institude, Boston, Mass.

Experimental Station, Amherst, Mass.

1715 Railway Exchange Building, Chicago, Ill.

U.S. Dept. Agriculture, Washington, D.C.

Experimental Station, Columbia, Mo.

Honorary Members of the Society for Horticultural Science, 1903-1904.

Andre, E.

Masters, Dr. M.T.

Wilson, Hon. J.
Paris, France, Rue Jacob 26, Paris, $6 \mathrm{Me}$ 41 Wellington St. Covent Garden, London, England U.S. Dept. Agriculture, Washington, D.C.

mented that our criticism of basic and applied science is of little value: "All academic subjects have considered themselves worthy in proportion as they serve no concrete purpose. We even speak of pure science, as if some science were impure. It is curious that subjects sought by human minds and hands are not pure when they serve those minds and hands in the affairs of life."

Bailey argued eloquently for the initiation of a solid research program in horticulture, including work in plant breeding, physiology, morphology, and many other subjects. In his presidential address at the 5th annual meeting of the Society for Horticultural Science at Jamestown, Va., 1907, Bailey articulated his view of horticulture as a developing science. He suggested that horticulture is an amalgam of different sciences, such as botany, genetics, soils, and others that developed separately in the LandGrant colleges. He suggested that the horticulturist-scientist develop a comprehensive research agenda. He clearly issued the charge that we 
were to follow in the next hundred years: "Everything is to be done, for everything is yet unfinished. There is not one subject that we can say is even fairly completed...our very civilization depends on man's relation to plants, and a good part of this relationship falls in the domain of the horticulturist...The opportunities of the horticulturist are just beginning to be recognized. ... Real horticultural research is only begun."

OtherASHS presidents echoed similar themes during the first decades of the 20th century, including Spencer Ambrose Beach, who became president in 1911. Beach asked the membership to consider the trend of intensification of agriculture in the U.S., pointing out that population growth and demand for horticultural products would significantly increase in coming decades. Beach also put forth a plea to request more financial support for horticultural research, claiming that horticulturists have been far too modest in demonstrating the success of their work. Similar comments can be heard today by our society's membership, suggesting that for the past one hundred years at least, our productivity has not been matched by our ability to recruit governmental support for our efforts. Many society presidents discussed specific areas of horticulture that were of concern, including vegetable and fruit production, or developing an academic department of horticulture at a Land Grant college.

By the mid-1920s, ASHS was growing rapidly and was already discussing how to pay for its expanding publication costs. Some 90 papers were delivered at the annual meeting in 1926, up from just 10 in 1903. In his presidential address, Eugene Auchter suggested that length limitations be placed on ASHS's annual proceedings papers, and he reinvigorated the discussion concerning the establishment of a society journal. Other presidents discussed the moral responsibility of those involved in research, and how the scientific method could be used to solve social problems.

The many disciplines within horticultural science that we have come to recognize did not all develop simultaneously within ASHS, but rather proceeded from a more pragmatic standpoint. At the beginning of the 20th century, edible crop production was of paramount importance, and naturally those involved with horticultural science focused on fruit and vegetable production. Ornamental plants did not become a large-scale focus of the work of the horticulturist until the late 1920s and early 1930s. Initially, woody plant and floriculture specialists depended on information generated by pomologists. As a commercial industry for ornamental plant materials grew around strong consumer demand, scientific developments in physiology, genetics, and biochemistry helped scientists understand and develop new woody plant materials. This was further enhanced in the decades directly following World War II. Demographic shifts in the U.S. population during this period, including the tremendous expansion of suburban living and its accompanying demand for ornamental plant materials, fueled significant developments in research. Today, the many subdisciplines within ASHS have had the benefit of at least seven decades of continued parallel growth with significant opportunities to interact and benefit from each other.

By the 1940s, many traditional subspecialties in horticultural research had been established. The results of a remarkable survey conducted among ASHS's membership was reported in 1945 by President Warren Mack, who indicated that the scope and range of horticultural research projects in U.S. institutions had increased dramatically, and showed no signs of slowing down. Our institutions were by that time involved in training horticultural scientists, giving instruction in short courses and in extension programs, and a wide variety of research programs. The increasing specialization of the horticultural research mission was already evident by this period, a trend that continues to this day.

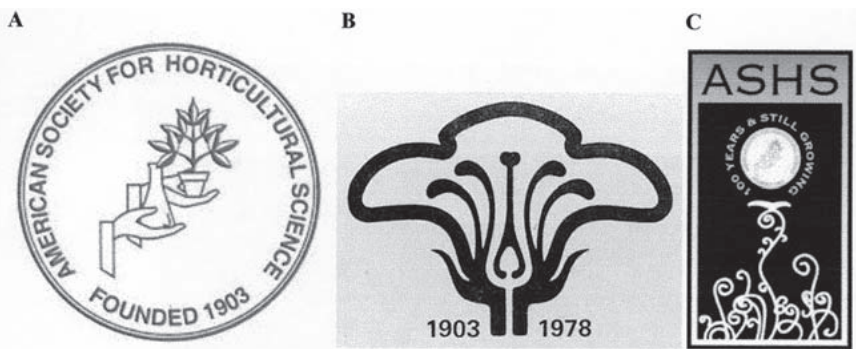

Fig. 2. ASHS logo, designed in 1959 (left); 75th anniversary (center); centennial (right).
By 1947, President Harold B. Tukey, Sr., was asking the same questions posed by Bailey more than 45 years earlier, but in a slightly different context. Tukey's vision was that the horticulturist is a link between the biologist and the practical user of plant materials. This bridging aspect of horticulture continues to be widely discussed by ASHS's membership, and is likely crucial to our continued success. In 1953, the 50th anniversary of the founding of ASHS, membership was 1700 with about 600 foreign members, and our Society was the largest horticultural science society in the world. In 1959, ASHS approved an official emblem (Fig. 2) designed by Marion Sheehan of the University of Florida, the familiar pair of hands holding a flask and a potted plant, representing people, science, and horticulture. The next 50 years have included decades of expansion for ASHS, and ASHS increased in complexity to face the new challenges that we encountered.

AnNual MEETings. ASHS has held regular annual meetings since the 1903 , missing only the war year of 1942 . However, in 1908 only a business meeting was held and in 1917 there were two meetings, one a special one held with the American Pomological Society. Until 1948, all meetings were held in conjunction with AAAS while from 1949 to 1967 meetings were held with the American Institute of Biological Sciences (AIBS). Subsequently we have organized our own meetings, four times in conjunction with the Canadian Horticultural Society, and three times as part of the International Horticultural Congress (1966 in College Park, Md., 1986 at Davis, Calif., and 2002 in Toronto, Canada.) Early meetings were generally held in hotels, but campus meetings became prominent in the 1950 s as participants sweated in unairconditioned university dorms. As our attendance increased in the 1980s meetings moved to convention centers with much better facilities but were accompanied by dramatic increases in registration costs.

Although the annual meetings were designed for presentations of scientific papers that were subsequently published in the Proceedings of our Society, they also became an occasion for fellowship and interaction between horticulturists from around the country. From 1905 until the late 1920s smokers were held under clouds of tobacco fumes where members joined in fellowship. This was the precursor of the excursions, and pre-and post-meeting tours, wine-and-cheese events, and special alumni bashes.

An ASHS banquet in 1904 was a prominent part of the meeting and continued for many years thereafter, often enriched by entertainment as well as merriment and drollery from stories and tales by members. The banquet became the venue for the presentation of presidential addresses, annual awards, as well as entertainment, but as meetings increased in size, the general banquet was discontinued in favor of an elaborate opening reception and the presidential address was delivered as a special convocation. However, the Extension and Industry Division still maintain their own banquet and the International Division sponsors a reception. With the demise of the banquet, award presentations were moved to a special ceremony before the business meeting. The awards and recognitions from ASHS kept enlarging, emphasizing best papers (later best poster) in various fields, collegiate branch awards, and eventually career awards. Although attempts were made to reduce the proliferation of awards this proved an almost impossible task. At present there are over 20 awards. A Fellows recognition program was initiated in 1965 and at that time all living ex-presidents were inducted. At present there are about a dozen inductees per year, with the number of fellows limited to $10 \%$ of membership. A Hall of Fame was initiated in 1990 with L.H. Bailey, and Gregor Mendel the first inductees. As of 2002 there were 27 members.

Plenary sections, colloquia, and workshops were added in the last quarter of the 20th century and have greatly increased the impact of our annual meeting. Attendance peaked at 1735 in 1995 at the joint meeting of ASHS and the Canadian Society for Horticultural Science in Montreal, Quebec, Canada. Venues for annual meetings from 1903-2003 are shown in Fig. 3.

\section{Publications}

The first decision of the new Society was to publish the proceedings of the annual meeting. In 1905, the combined Proceedings of the 1903 and 1904 meeting were issued containing seven papers from the 1903 meeting; The Mangosteen, Queen of Tropical Fruit by David G. Fairchild, was the first paper. By 1933, the Proceedings required semi- 
annual publication to accommodate the growing number of papers. The Proceedings were issued from 1941 to 1968 in the familiar blue volumes printed by the W.F. Humphrey Press, Geneva, N.Y. During World War II, when travel restrictions were imposed, some papers were published which had not been presented orally and from that point on the Proceedings was considered such in name only. In 1969, the Proceedings was changed in name to the Journal and was issued bimonthly. In 1966, a second journal dubbed HortScience was published emphasizing shorter papers and other features. A society monthly communication, The ASHS Newsletter, was initiated in 1985 and HortTechnology was added in 1990. The growth of ASHS publications over 100 years is shown in Fig. 4. The relationship between dues and pages received is shown in Fig. 5. Publication editors are included in Table 2.

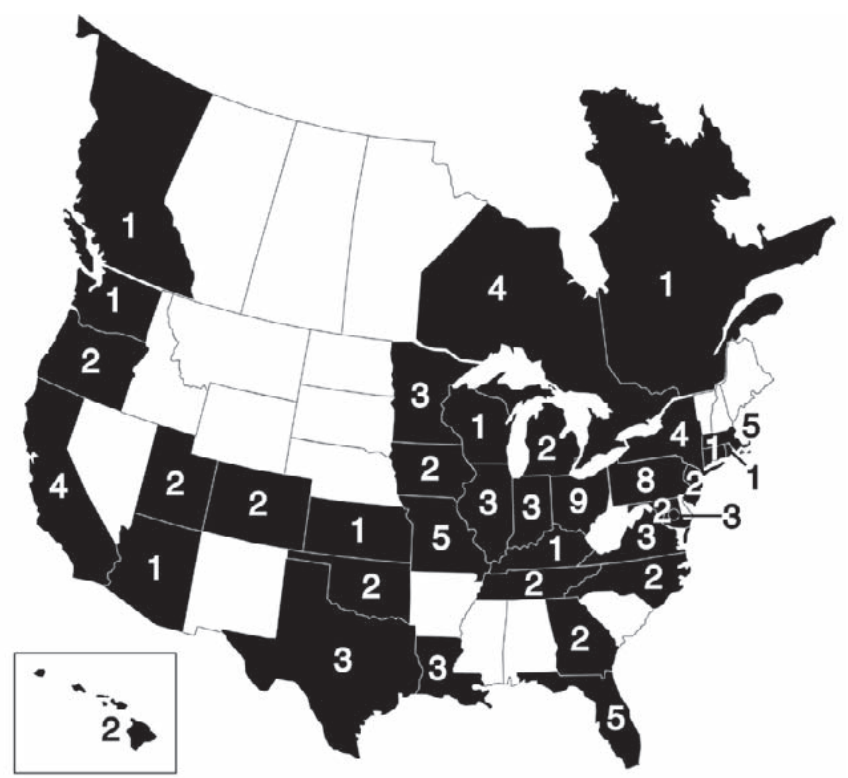

Fig. 3. Venues for ASHS Annual Meetings, 1903-2003. The number in each state or province refers to multiple meeting.

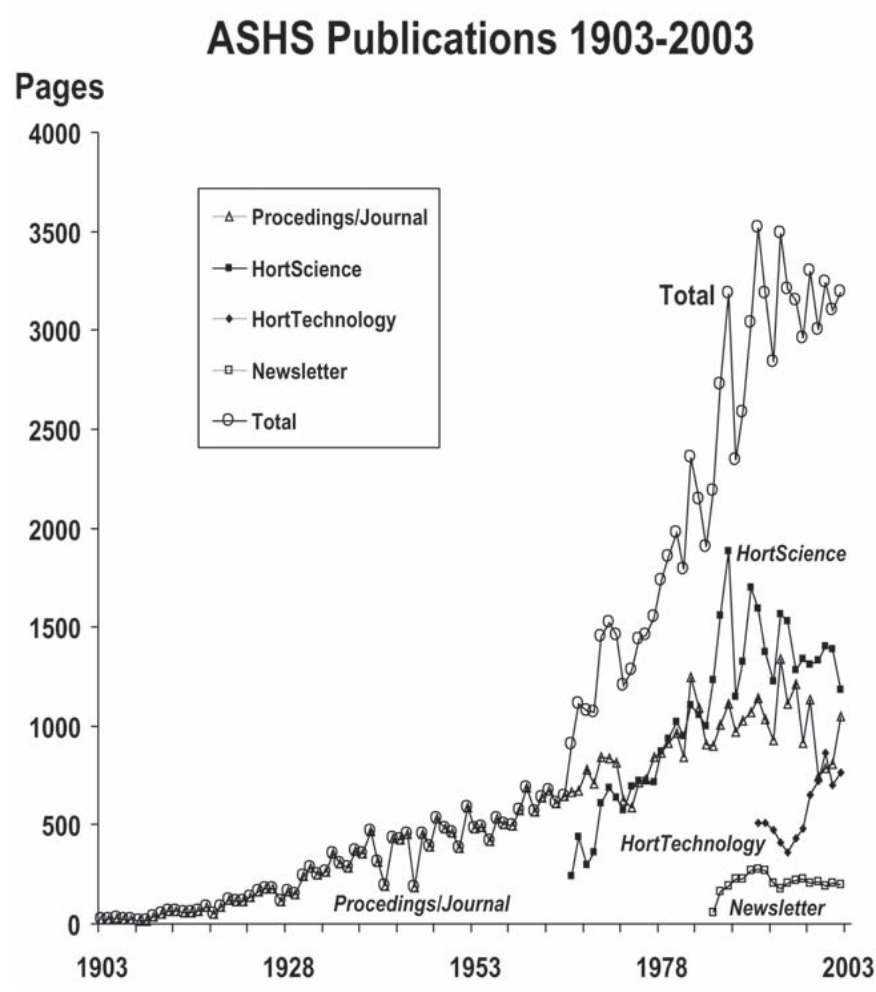

Fig. 4. Growth of ASHS publications. Proceedings pages divided by 2.5 to be equivalent to Journal pages.
ASHS has dabbled sporadically in book publication and bulletins. In the 1960s, the first book project was volume IV of Plant Analysis and Fertilizer Problems, containing papers of a colloquium presented in connection with the 16th International Horticultural Congress held in 1962. The second was the proceedings of a 1965 conference on undergraduate education in horticultural science held at the University of Illinois in 1965. Jules Janick proposed that ASHS publish an Annual Review of Horticultural Science but a committee chaired by Paul Larson decided that it would be hard to fill, and the idea was dropped, and so Horticultural Reviews and later Plant Breeding Reviews, although sponsored by ASHS, were published by a succession of for-profit publishers. They continue to provide a scholarly forum for detailed reviews of horticultural subjects. From the late 1960s to the early 1990s ASHS sold reprints of symposia and workshops as separates. In 1996, ASHS, chaffing at the success of some if its sister societies formed ASHS Press and has since published about 20 volumes. In 2003, ASHS Press was dropped, but a broader entity, ASHS Communications may be adopted to emphasize a wider scope of communication efforts.

Developments of the computer and internet technology have been a powerful force in the last quarter of the 20th century, and ASHS is still adapting to it. In 1986, headquarters became computerized and in 1987 set up page-making for the newsletter, and subsequently for all of our journals. The transformation of our hard-copy journals to an online system has been more difficult but has now been completed and our journals are now available in both formats. ASHS is in the middle of a project to digitize all past journals of ASHS and make them accessible via the internet.

\section{Society Structure}

OfFiCERs. In the early years officers consisted of a president, three vice presidents, secretary-treasurer, assistant secretary, and editor/ business manager. Many officers, including editors, served for long periods of time, which provided continuity (Table 2). Bailey served

\section{ASHS Dues 1903-2003}

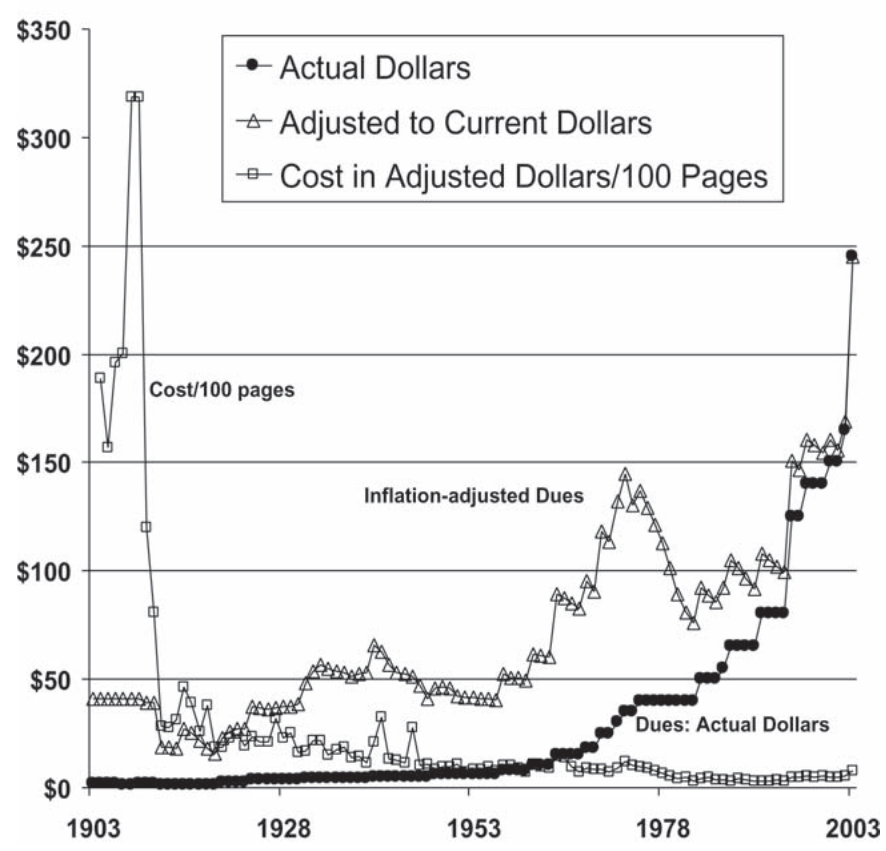

Fig. 5. ASHS dues (1903-2003) in actual and inflation-adjusted dollars and member-allocated costs/100 pages of journals received. Total pages received by members were obtained from calculation in Fig. 4 with data for 2003 considered unchanged from 2002. Dues assume member receives all journals, a policy made optional in 1993. The member-allocated cost of 100 pages is determined by dividing total pages of all journals and the Newsletter by dues adjusted for inflation (in 2003 dollars) and multiplying by 100. Proceedings pages were divided by 2.5 to be equivalent in content to present journal pages. When Proceedings were combined in 1903-1904 and 1908-1909, the pages were allocated for each year by dividing actual pages by 2 . 
Table 2. ASHS officers, 1903-2003 (see also Fig. 6).

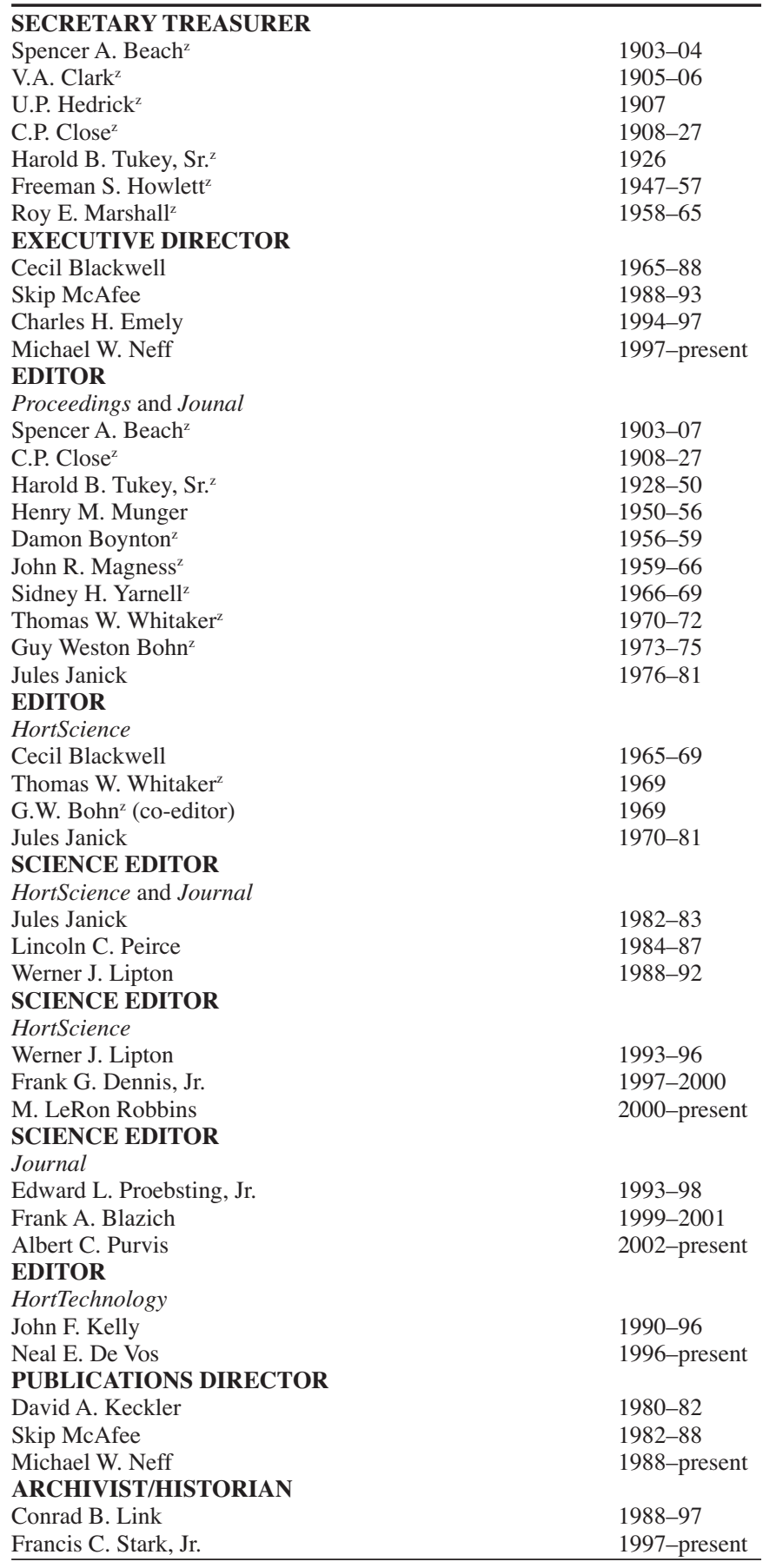

${ }^{2}$ Deceased.

as President from 1903-1907; W.A. Taylor served from 1908-1910 but henceforth the president changed annually, except that J.C. Miller served in both 1943 and 1944, reflecting the war-time suspension of the annual meeting. Our officers were meticulous and frugal; expenses of C.P. Close to attend the 1926 meeting in Philadelphia are listed as follows in the treasurer's report for 1927:

Railroad fare College Park, Md to Philadelphia

$\$ 4.63$

Tip to hotel porter in Philadelphia

0.10

Twelve meals in Philadelphia

Lodging 4 days at $\$ 3.50$ per day

Twelve car fares at $8 \notin$ each

Telegram to E.J. Krans, Madison, Wis

Railroad fare Philadelphia to Washinton

Three car fares Washington to College Park, Md.

Total

9.10

14.00

0.96

.73

2.59

0.24

$\$ 32.30$
Officers were selected by a nominating committee, but, beginning in the 1970s, coincident with the reorganization of ASHS and in an effort to make ASHS more democratic, elections were held from choices proposed by a nominations committee, including president elect, and vice presidents (now Research, Extension, Industry, Education, and International). A brief biography of each ASHS president along with their addresses is presented as a special volume for the ASHS Centennial; this volume is an update of the 1993 volume of ASHS Presidential Addresses (Janick, 1993). The presidents of ASHS from 1903 to 2003 are shown in Fig. 6.

EXECUTIVE DIRECTORS AND HEADQUARTERS. Until 1965 our society was operated by a series of secretary treasurers and editors who operated out of their institution or home. However, with its growth, ASHS decided to operate under professional management. Cecil Blackwell was hired as our first executive director and served from 1965-1988. During that time, he served as editor of the newly formed journal called HortScience. Headquarters were first located in St. Joseph, Mich., in facilities that President W. A. (Tex) Frazier would later describe as "so modest as to be immodest."

In an attempt to consolidate the major horticultural societies, ASHS moved in 1974 to River Farm (once owned by George Washington) in Alexandria, Va., in facilities of the American Horticulture Society but ASHS was, in fact, a renter not an owner. In 1979, in an effort to own its own headquarters and be Master of its Domain, ASHS purchased a converted bank building at 701 North St. Asaph Street, Alexandria. In 1990, the building was sold at a huge profit and a new headquarters (condominium) was purchased at 113 South West Street, Alexandria. Then, in a comedy (or tragedy) of errors, the condominium was sold in 1995 and ASHS moved to a larger property at 600 Cameron Street, Alexandria. However, it soon became clear that the mortgage was unsustainable in light of a membership decline, and in 1999 this property was sold and ASHS leased facilities at 113 South West Street, the same building it once owned but on a different floor.

Subsequent permanent executive directors included Skip MacAfee (1988-1993), Charles H. Emely (1994-1997), and now MichaelW. Neff (1997-present). The Executive Directors and a changing board often have operated in a state of tension and one-by-one the past executive directors were eased or pushed out of office. Mike Neff is determined to break the tradition.

THE WORKING GROUP CONCEPT. The principal subdivisions of ASHS had been commodity based since 1953 when three sections were organized: Fruit, Vegetable Crops, and Floriculture and Ornamental Horticulture. In 1974-75, President H.J. Bukovac organized an evaluation task force to study the society's structure with an eye on reorganizing The committee included A.H. Thompson (chair), H.J. Carew, E.A. Crosby, J.F. Gerber, and W.L. Sims. Their feeling was that the horticultural interests of ASHS were necessarily fluid and dynamic and should be self-regulating. ASHS subsequently was reorganized into Divisions containing a series of working groups consisting of members self-selected to pursue special interests. These groups sink or swim based on the interests and vigor of the participants. The divisions were to be managed by a series of elected vice presidents with the fond hope that the grandiose title would give status to the operations of ASHS. Events have borne out the wisdom of this decision; the concept was workable and the organization has flourished.

REgIONAL SECTIONS AND STUDENT BRANCHES. As ASHS grew regional branches were formed. At one time there were five: Northeastern, Southern, Great Plains, Midwestern, Western, and Caribbean. At the present time the Northeastern, Western, and Southern regional meetings continue, with the Southern Region very active. The Caribbean Region met in different countries in the area and when South America was added the name was changed to ASHS Tropical Region. Papers were presented in English and Spanish with most meetings outside of the U.S. in cooperation with various Hispanic organizations. However, in 1988, the ASHS council, David Fagan, advised ASHS to separate this Regional Branch from ASHS, since financial decisions were being made in the name of ASHS by non-ASHS members. (In retrospect, this was an unfortunate decision.) As a result the Tropical Region reformed itself as the Interamerican Society for Tropical Horticulture, affiliated with, but a distinct organization from, ASHS, and the new society prospers. 
Fig. 6. ASHS Presidents, 1903-2003

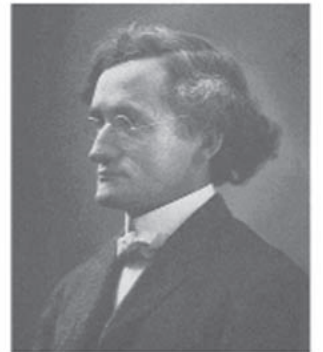

Liberty Hyde Bailey, 1903-1907

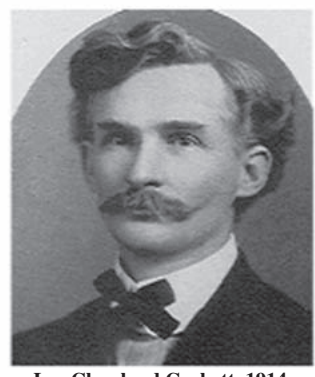

Lee Cleveland Corbett, 1914

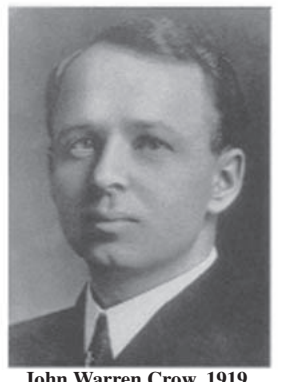

John Warren Crow, 1919

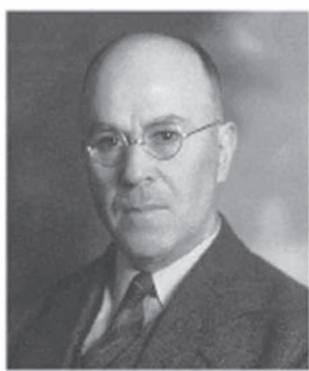

Maxwell Jay Dorsey, 1924
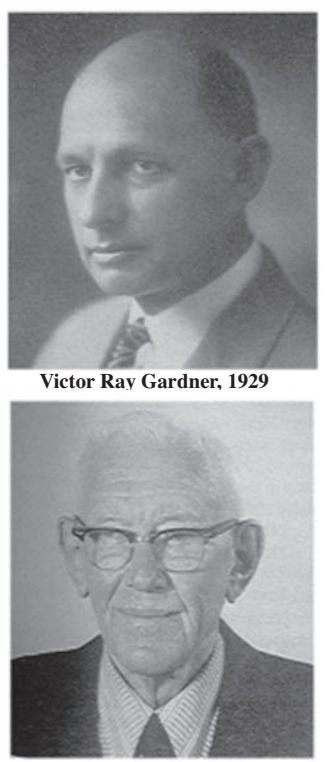

John Robert Magness, 1934

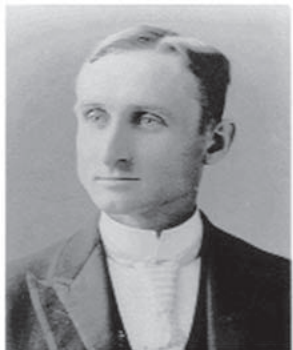

William Alton Taylor, 1908-1910

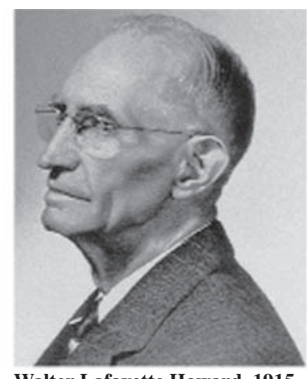

Walter Lafayette Howard, 1915

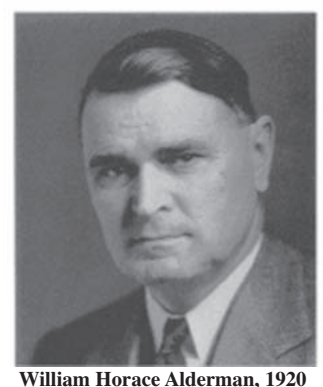

William Horace Alderman, 192

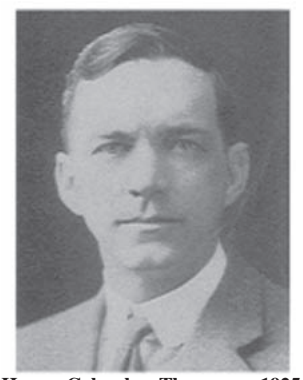

Homer Columbus Thompson, 1925

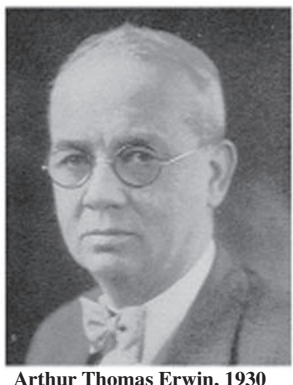

Arthur Thomas Erwin. 1930

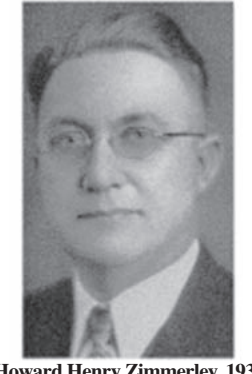

Howard Henry Zimmerley, 193

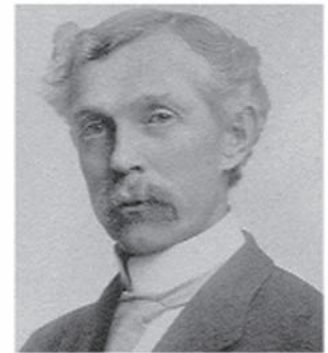

Spencer Ambrose Beach, 1911

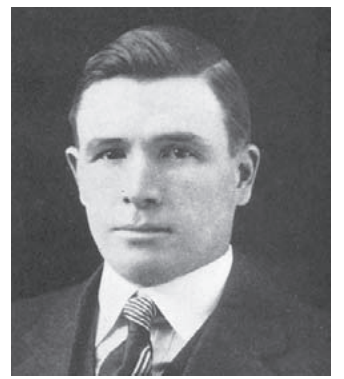

Maurice Adin Blake, 1916

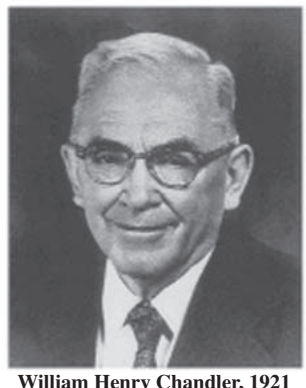

William Henry Chandler, 1921

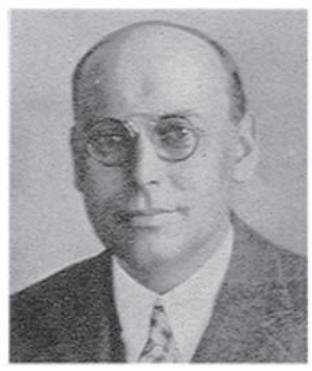

Eugene Curtis Auchter, 1926

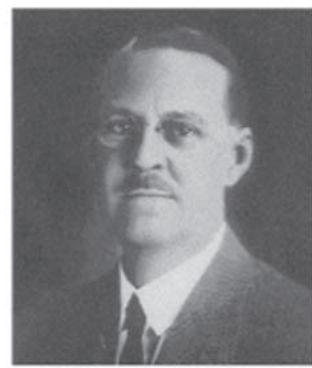

Thomas Hubbard McHatton, 1931

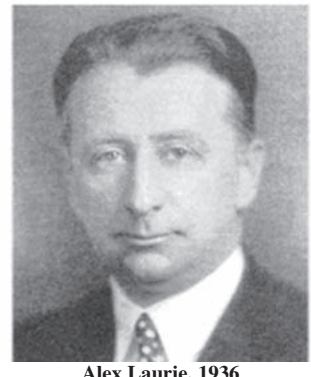

Alex Laurie, 1936

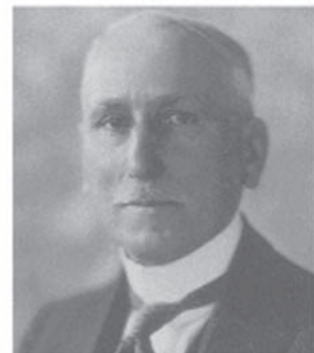

William Terrill Macoun, 1912

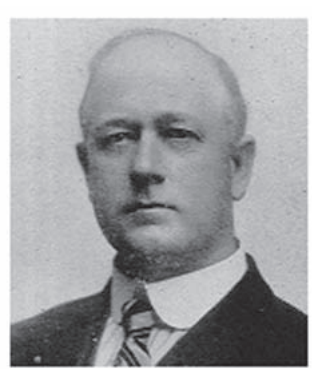

Thomas Carskadon Johnson, 1917

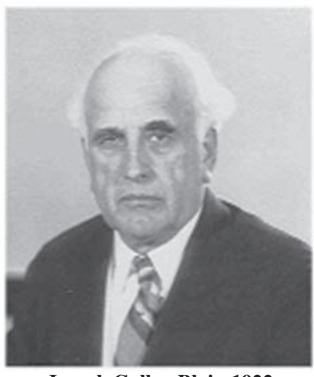

Joseph Cullen Blair, 1922

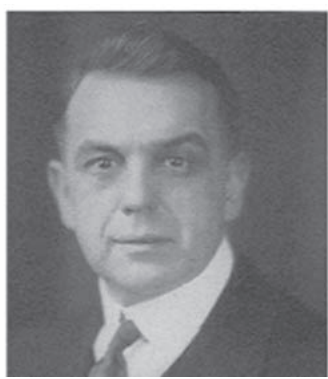

Ezra Jacob Kraus, 1927

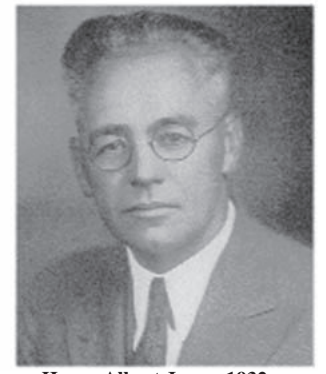

Henrv Albert .Jones. 1932

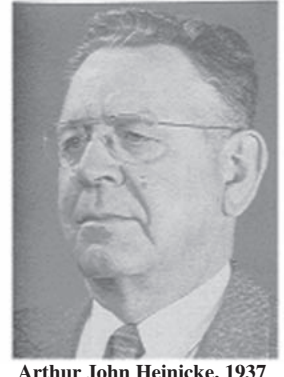

Arthur John Heinicke, 1937

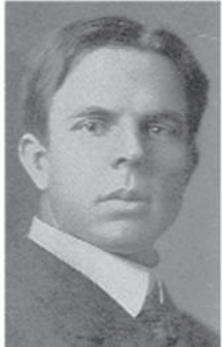

Ulysses Prentiss Hedrick, 1913

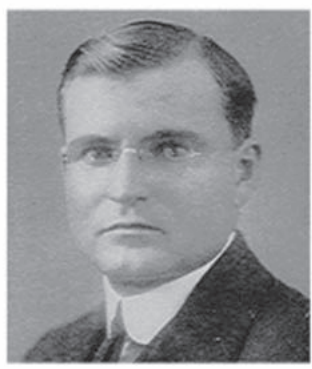

Charles Adam McCue, 1918

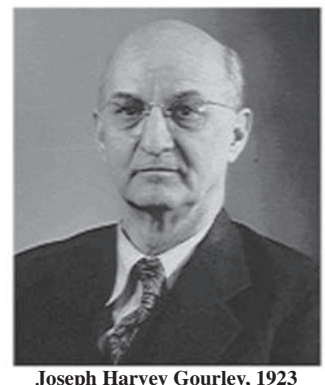

Joseph Harvey Gourley, 1923

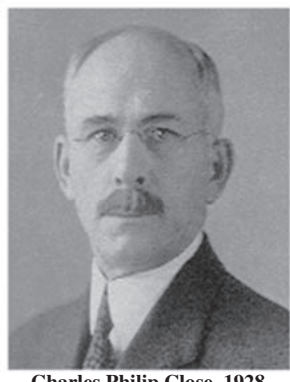

Charles Philip Close, 1928

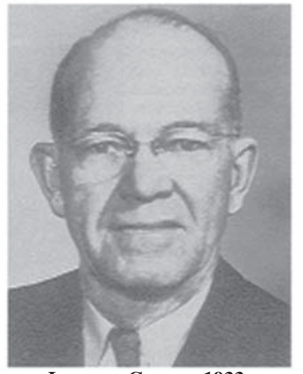

Laurenz Greene. 1933

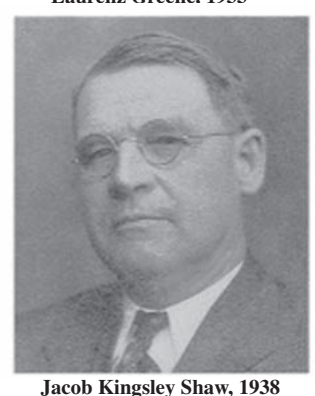

Jacob Kingsley Shaw, 1938

HortScience, Vol. 38(5), August 2003 

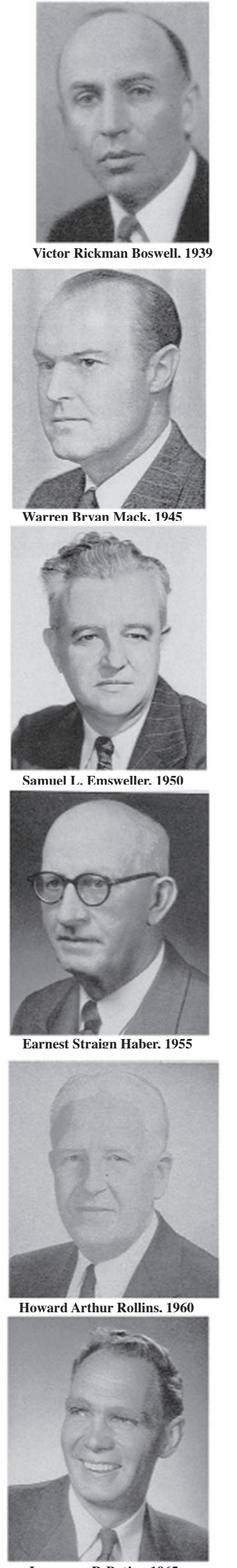
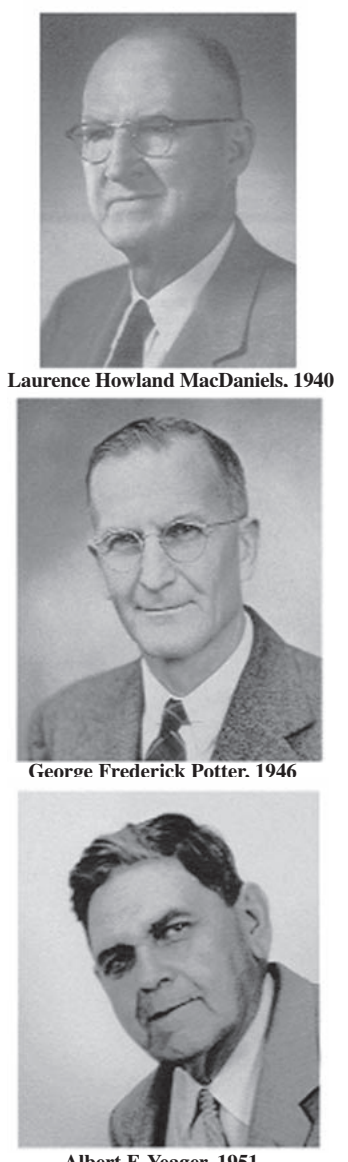

Albert F. Yeager. 1951

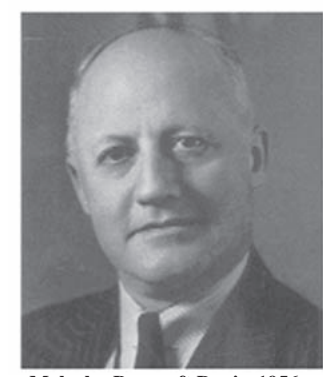

Malcolm Bancroft Davis. 1956

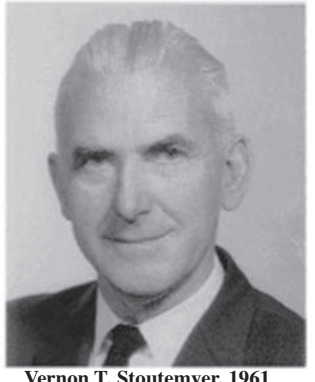

Vernon T. Stoutemyer, 1961

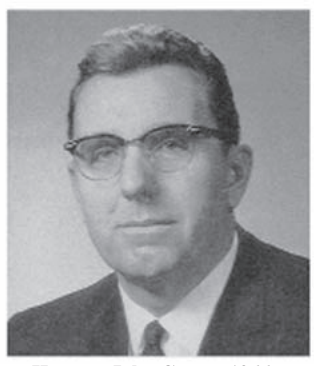

Herman John Carew, 1966
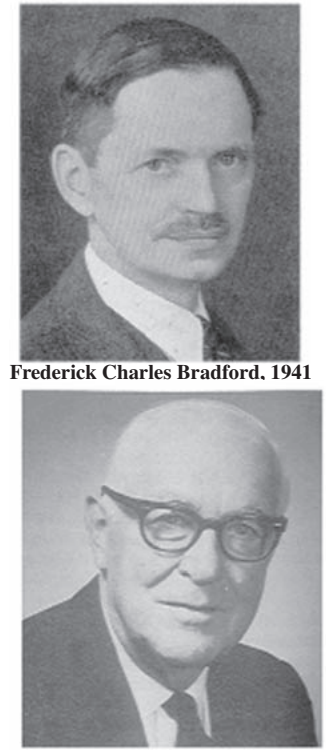

Harold Bradford Tukev. 1947

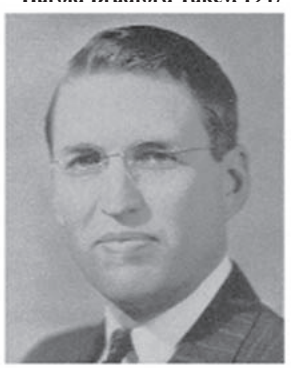

Kenneth Post. 1952

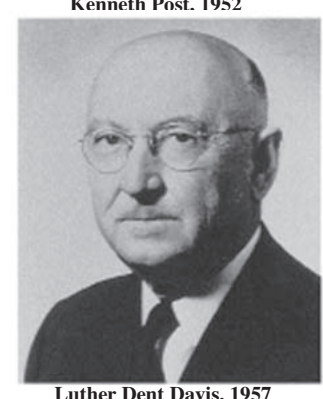

Luther Dent Davis. 1957

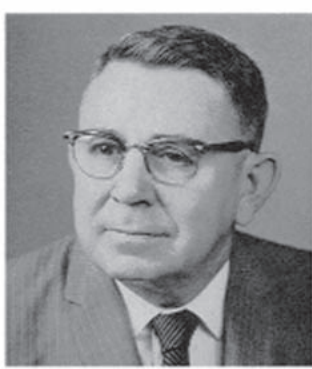

Frank Stover .Jamison. 1962

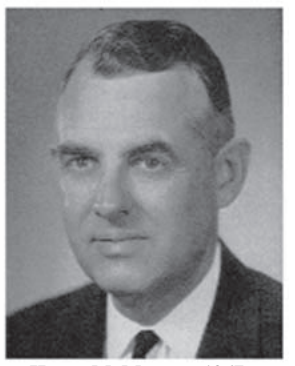

Henry M. Munger, 1967

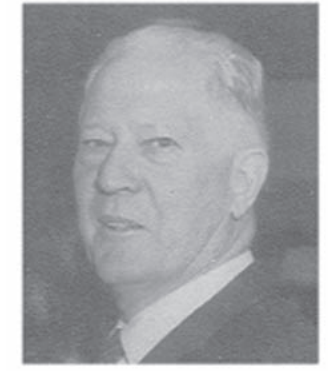

Julian Creighton Millers, 1942-1943

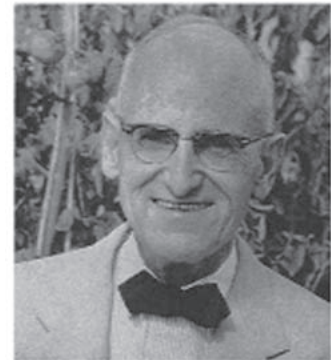

James Edward Knott, 1948

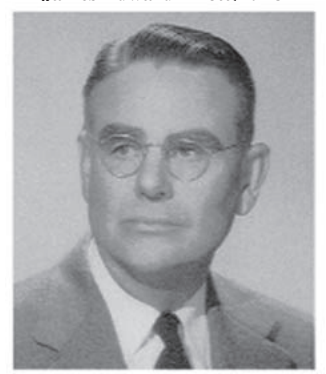

Sidnev Howe Yarnell. 1953

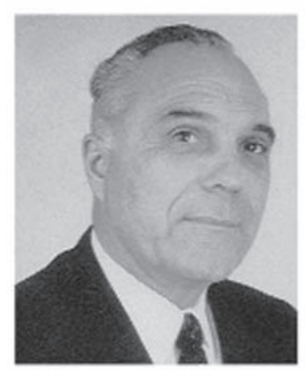

Wilbur Tibbits Pentzer, 1958

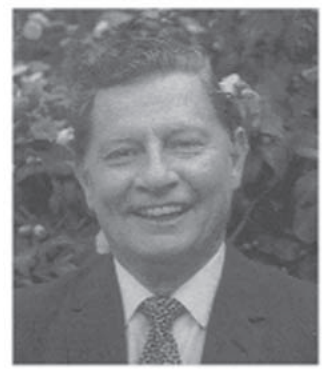

Walter Reuther. 1963

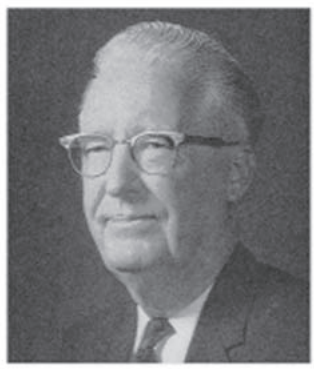

Neil Wade Stuart, 1968

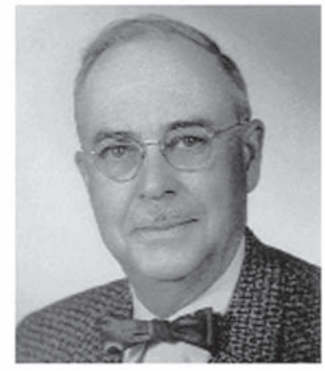

Warren Porter Tufts. 1944

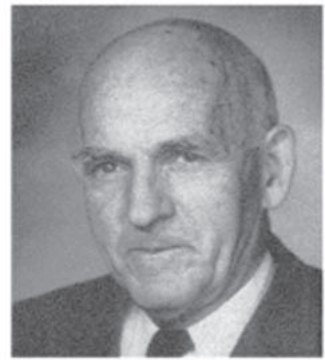

George McMillan Darrow, 1949

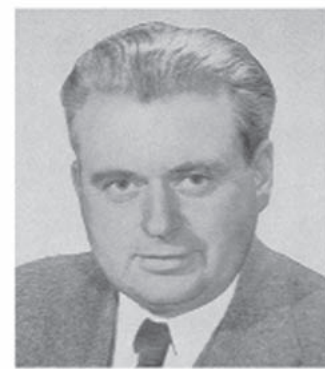

Frank Patrick Cullinan. 1954

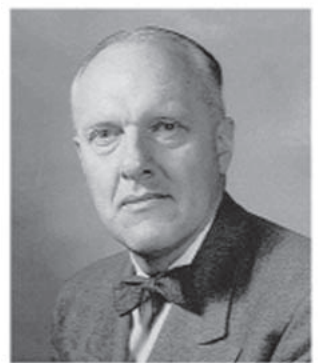

Freeman Smith Howlett. 1959

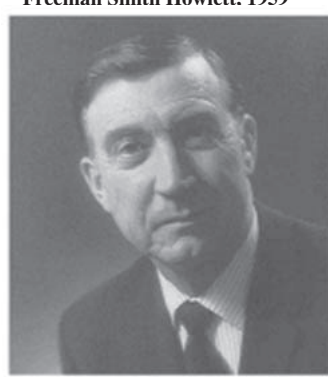

Russell E. Larson, 1964

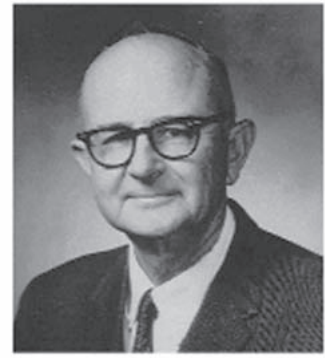

William Allen Frazier, 1969 

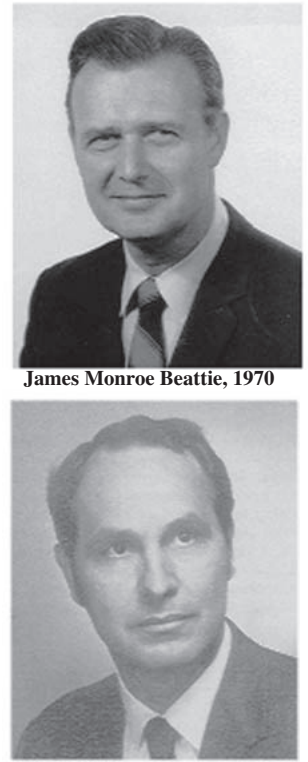

M. John Bukovac, 1975

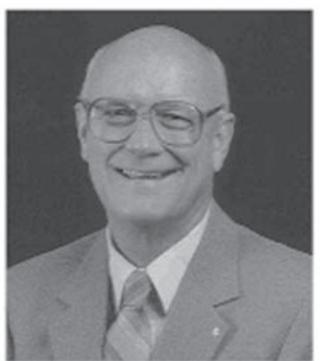

William Lynn Sims, 1980

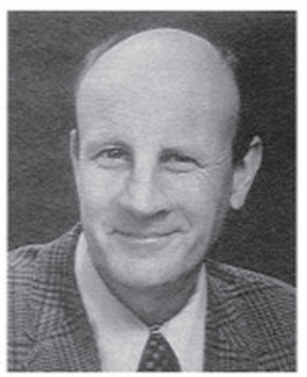

Dermot Patrick Coyne, 1985

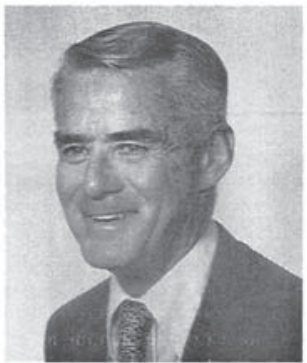

George Conner Martin, 1990

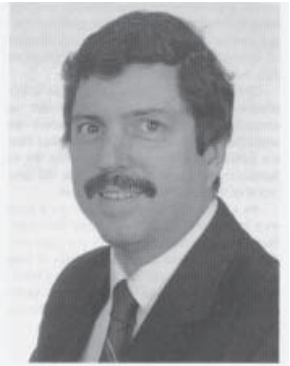

Daniel Cantliffe, 1995

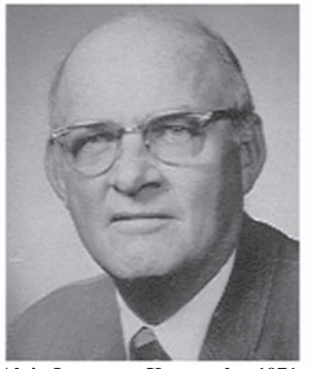

Alvin Lawrence Kenworthy, 1971

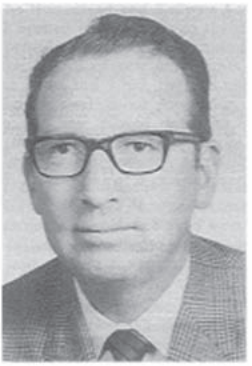

Robert Paul Larsen, 1976

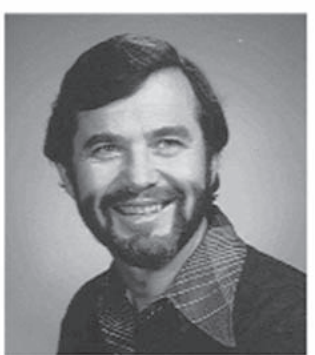

Conrad John Weiser, 1981

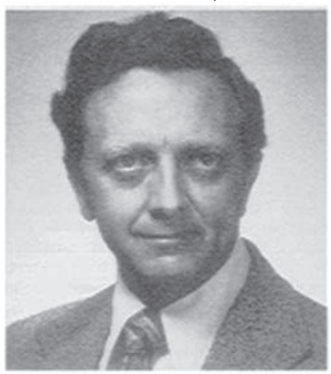

John Francis Kelly, 1986

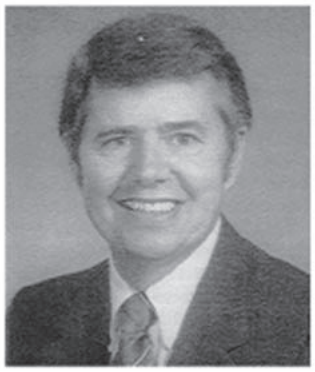

Richard L. Lower, 1991

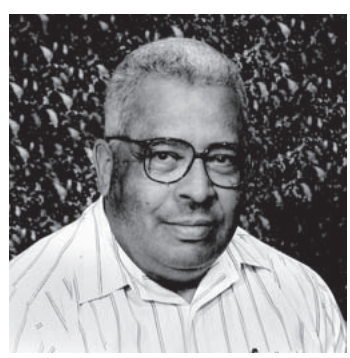

Adel Kader, 1996
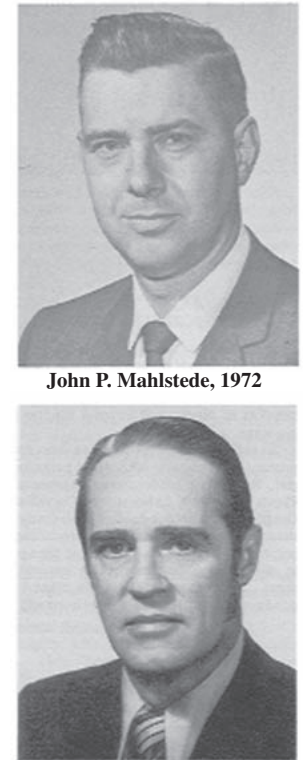

Edwin Andrew Crosby, 1977

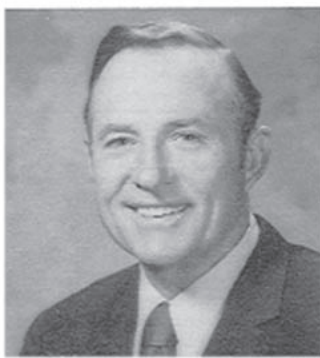

Warren S. Barham, 1982

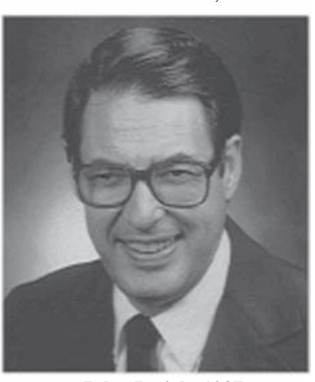

Jules Janick, 1987

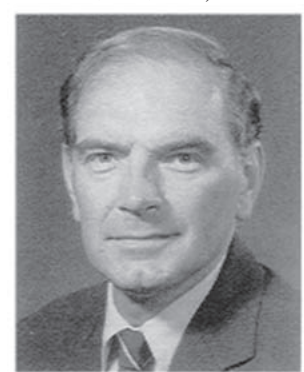

Thomas A. Fretz, 1992

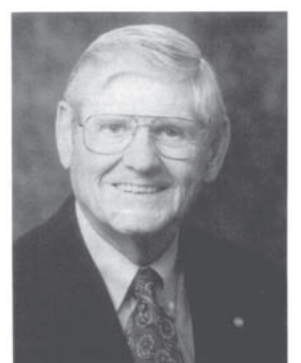

Donald Maynard, 1997

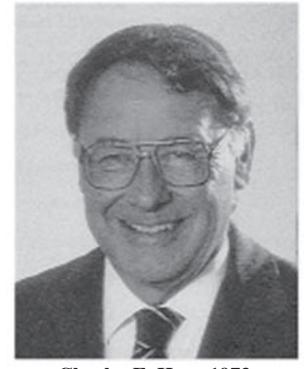

Charles E. Hess, 1973

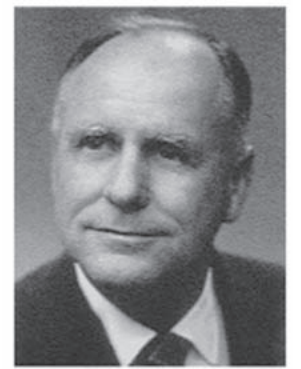

Alfred H. Krezdorn, 1978

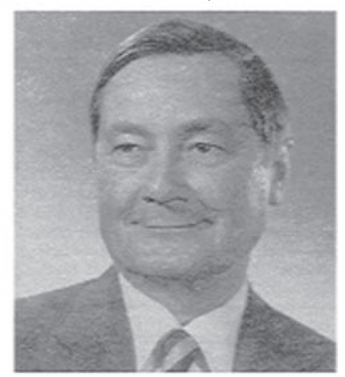

John George Seeley, 1983

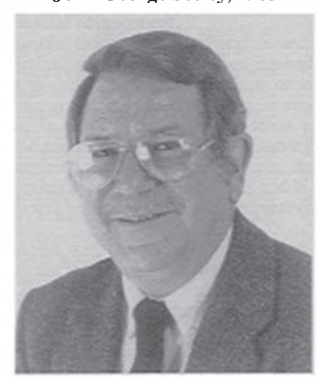

James Norman Moore, 1988

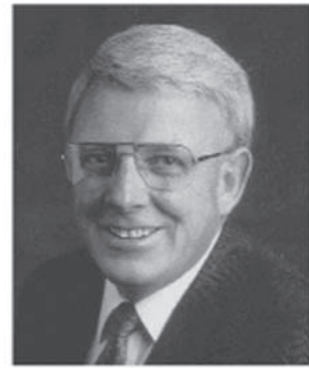

M. Allen Stevens, 1993

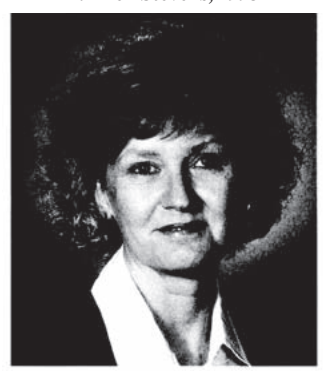

Wanda Collins, 1998

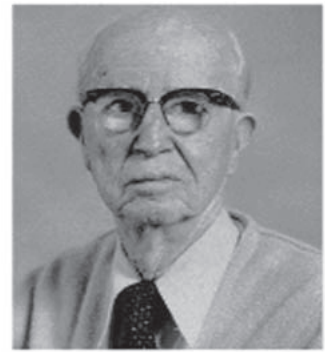

Thomas Wallace Whitaker, 1974

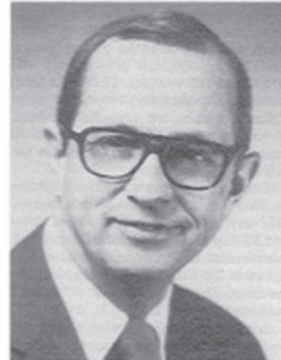

Warren H. Gabelman, 1979

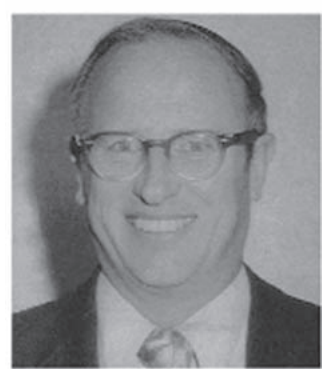

Edward Louis Proebsting, Jr, 1984

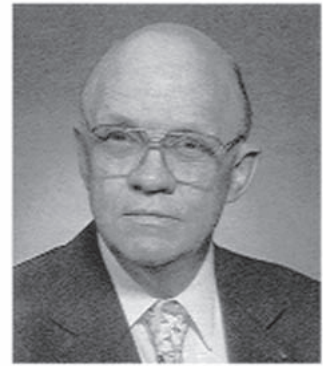

Roy Axel Larson, 1989

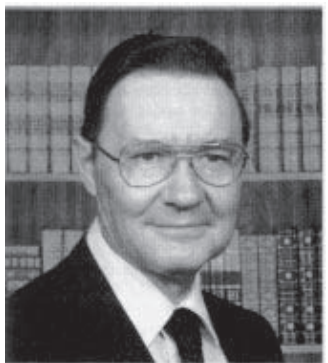

Benton Storey, 1994

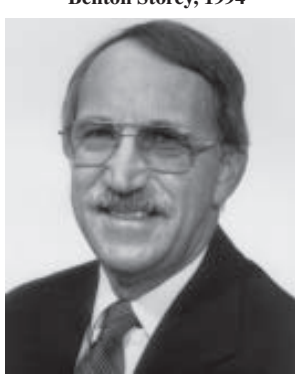

Fredrick Bliss, 1999 

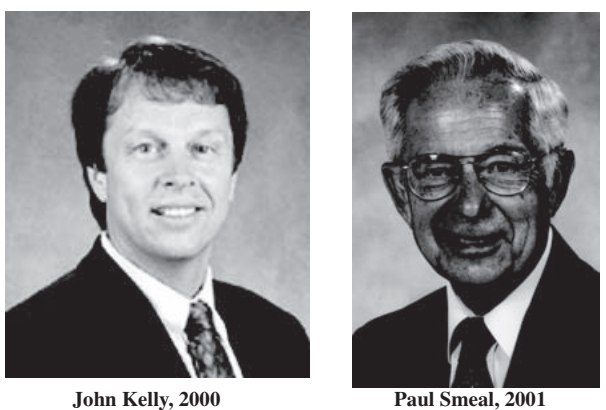

ASHS has always been interested in horticultural education and has long had junior (now student) branches whose activities are an important part of annual meetings. ASHS serves as a clearing house for horticulture clubs, sponsors various awards, and recognizes superior students.

\section{The Future of ASHS}

Membership in ASHS rapidly increased from the original 53 members in 1903 (Table 1). Fifty years later, ASHS had 1700 members and was the largest horticultural society in the world. Membership peaked in 1990 at 5000 members, of which one-third were international. Since that time membership has eroded as a consequence of the merging of horticulture departments in the Land Grant universities, the presence of nonhorticulturists in horticulture departments, as well as the rising cost of membership which has impacted student membership. Membership in 2002 was about 3800 , more than twice that of 1953 . The decline in membership from the peak is worrisome and maintaining membership clearly will be a major challenge for our Society in the near future. The future of horticulture and the relevance of our Society has never been stronger as our products - fruit, vegetables, flowers, ornamentals - continue to find increasing demand in the U.S. and the World. However, horticultural crop production in the U.S. is being carried out by a smaller industry as a result of increased efficiency, and increased imports. Yet, increasing home ownership has made the green industry serving amenity horticulture the most dynamic part of the new horticulture, and this area has attracted most of our students. At the same time, horticultural research has become specialized and at present many involved in the new science are more discipline-oriented than commodity-oriented and have sought their professional home outside of our Society. It will be the challenge of our Society to adapt to these changes.

\section{HORTICULTURE: RETROSPECT AND PROSPECT}

Paraphrasing Abraham Lincoln's final comments in his first inaugural address, we find ourselves loath to close this historical review without reflection about horticulture, and horticultural science, the accomplishments of ASHS, and the future of our profession and our Society. The theme of the Centennial is 100 Years of ASHS \& Still Growing, and we are convinced this is true. However, we view growth in the future in qualitative rather than quantitative terms. We must be growing better, stronger, and more relevant to the problems we face, adapting to our future, just as our founders responded to their future. They succeeded brilliantly in making horticultural science a dynamic part of both agriculture and science. We must continue to carry this torch because we have a responsibility to make sure that our science is on the cutting edge but relevant to the needs of humanity. We must continue to find explanations for plant growth, development, and heredity and also be sure that the progress made in the scientific arena is translated to the betterment of producer, consumer, and all humankind.

We are convinced that the words and thoughts of Liberty Hyde Bailey in his first great presidential addresses reverberate still. We agree with Bailey that horticulture touches our lives at every point. We affirm that the science of horticulture is intent on unraveling the physiology of plants in the broadest sense, and the modification of plants through genetics and breeding. We are deeply aware that horticulture has an affairs side, which involves applied technology and a complex industry. Finally, we cannot and will not ignore the artistic side of horticulture: the love of plants, the love of gardens and the use of plants to heighten the beauty and meaning of the landscape. Horticulture always has and will continue to be deeply
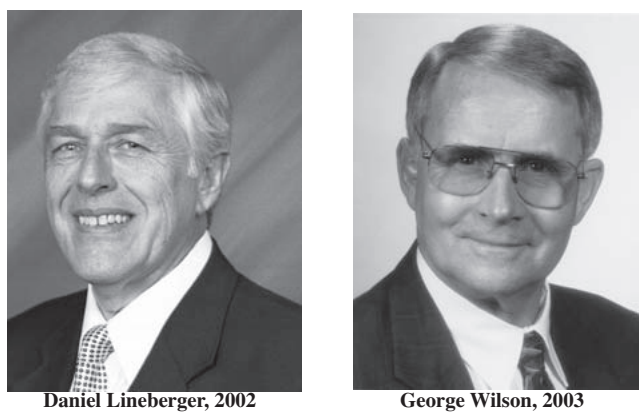

concerned with the environment and environmental issues.

Horticulture has come a long way in the last century and is now in the enviable position of being the most technologically advanced of all the agricultural commodity disciplines. It is broad in its science but reflects humanism in the best sense of the word. Horticulture is now recognized as the key to health and well-being, the key to the alleviation of rural poverty, and a necessary component of human happiness. The goal of our founders was to claim a place at the table of agricultural science and to gain respect for what was considered trivial and common. Our goal in the future is the same; we must continue to be leaders in science and we must promote our skills to the betterment of the human condition. In view of the increasing importance of the private sector in research ASHS must serve to galvanize the leadership of public and private sectors in a revitalized spirit of cooperation. As public sector horticulture programs continue to be faced with budget shortfalls, our ability to articulate this dual mission will be crucial to our success. Our Society cannot rest on it laurels but must strive to be innovative, progressive, and imaginative. In the words of Lincoln: "we must think anew, and act anew."

This year saw the untimely passing of Dermot Coyne, an inspiring figure in American horticulture. His statement at the close of his presidential address bears repeating and is an appropriate way to close: "We can take pride in being members of this prestigious horticultural society since it has contributed so much to the total horticultural industry, to science and to art, to the economy of our states and nation, to humanity at home and overseas, and to the development of attractive environments. We can continue through our work to affirm and to strengthen the lives of others where they have grown weak through hunger and malnutrition, we can build hope where people are mired in despair through poverty, and we can enhance beauty of place and of mind where starkness and austerity now prevail. It is an immense challenge: each horticulturist can meet it in various ways based on individual motivation, skills, and circumstances. When your legacy is written, may your epitaph simply say: 'they gave their best in their times and their dreams were fulfilled'."

\section{Literature Cited}

Anonymous. 1871. Bulletin of the Bussey Institution. Harvard Univ., Cambridge, Mass.

Arditti, J. 1989. Introduction to Lewis Knudson. 1922. Nonsymbiotic germination of orchid seeds. Bot. Gaz. 73:1-25. In: J. Janick (ed.). Classic papers in horticultural science. p. 14-18. Prentice-Hall, Englewood Cliffs, N.J.

Avery, Jr., G.S. and E.B. Johnston. 1947. Hormones and horticulture: The use of special chemicals in plant growth. McGraw-Hill, New York.

Charles, D. 2001. Lords of the harvest: Biotech, big money, and the future of food. Perseus Publ., Cambridge, Mass.

Coyne, D.1989. Introduction to J.C. Walker and Rose Smith. 1930. Effect of environmental factors upon the resistance of cabbed to yellows. J. Agr. Res. 41(1)1-15. In: J. Janick (ed.). Classic papers in horticultural science. p. 526-528. Prentice-Hall, Englewood Cliffs, N.J.

Edwards, E.E. 1940. American agriculture - The first 300 years. In: The Yearbook of Agriculture, 1940. USDA, GPO, Wash., D.C. p. 171-276.

Eigsti, O.J. 1989. Introduction to H. Kihara. 1951. Triploid watermelons. Proc. Amer. Soc. Hort. Sci. 58:217-230. In: J. Janick (ed.). Classic papers in horticultural science. p. 554-556. Prentice-Hall, Englewood Cliffs, N.J.

Elfving, D.E. 1989. Introduction to S.D. Goldberg and M. Shmueli. 1970. Drip irrigation: A method used under arid and desert condition of high water and soil salinity. Trans. Amer. Soc. Agr. Eng. 13(1)38-41. In: J. Janick (ed.). Classic papers in horticultural science. p. 392-395. Prentice-Hall, Englewood Cliffs, N.J. 
Faust, M. 1989. Introduction to Arthur J. Heinicke and Norman F. Childers. 1937. The daily rate of photosynthesis during the growing season of 1935 , of a young apple tree of bearing age. Cornell Univ. Expt. Sta. Mem. 201. In: J Janick (ed.). Classic papers in horticultural science. p. 276-278. PrenticeHall, Englewood Cliffs, N.J.

Fletcher, H.H. 1969. Story of the Royal Horticultural Society (1804-1969). Oxford Univ. Publ for RHS., Oxford.

Gabelman, W.J. 1989. Introduction to H.A. Jones and A. E. Clarke 1942. Inheritance of male steriliy in the onion and the production of hybrid seed. Proc. Amer. Soc.. Hort. Sci. 4:189-194. In: J. Janick (ed.). Classic papers in horticultural science. p. 544-547.Prentice-Hall, Englewood Cliffs, N.J.

Howlett, F.S. 1953. In recognition of our fiftieth anniversary. Proc. Amer. Soc. Hort. Sci.62:1-3.

Janick, J. 1989a. Classic papers in horticultural science. Prentice Hall, Englewood Cliffs, N.J.

Janick. J. 1989b. Introduction to Gregor Mendel 1865. Experiments on plant hybrids (Versuche uber Pflanzen-Hybriden). Verhandlungen des Naturforschenden den Verlienes in Brunn 4:33-47. In: J. Janick (ed.). Classic papers in horticultural science. p. 406-412. Prentice-Hall, Englewood Cliffs, N.J.

Janick, J. 1994. Presidential addresses. Amer. Soc. Hort. Sci., Alex., Va.

Jones, D.F. 1944. A biographical memoir of Edward Murray East, 1879-1938. Nat. Acad. Sci. Biogr. p. 217-242

Kerr, N.A. 1987. The legacy: Acentennial history of the state agricultural experiment stations, 1887-1987. Mo. Agr. Expt. Sta. Univ. Mo.-Columbia.
Korcak, R.F. 1992. Early roots of the organic movement: A plant nutrition perspective. HortTechnology 2:263-267.

Langhans, R.W. 1989. Introdution to Kenneth Post 1934. Production of early blooms of chrysanthemums by the use of black cloth to reduce the length of day. N.Y. State. Expt. Sta. Bul. 594. In: J. Janick (ed.). Classic papers in horticultural science. p. 241-244. Prentice-Hall, Englewood Cliffs, N.J.

Looney, N.F. 1997. Hormones and horticulture. HortScience 32:1014-1018.

Paarlberg, D. and P. Paarlberg. 2000. The agricultural revolution of the 20th century. Iowa State Univ. Press., Ames.

Schmidt, L.B. 1930. The agricultural revolution in the United States, 1860-1930. Science 72:585-594.

Tiefenthaler, A.E., I.L. Goldman, and W.F. Tracy. 2003. Corn and vegetable yield trends, 1900-present. HortScience (in press).

Warren, G.F. 1998. Increase in crop yield in the United States in the 20th century. Weed Technol. 12:752-760.

Weller,S.C, and J.R. Frank. 1989. Introduction to Paul C. Marth and John W. Mitchell. 1944. 2,4-dichlorophenoxyacetic acid as a differential herbicide. Bot. Gaz. 106. In: J. Janick (ed.). Classic papers in horticultural science. p. 224-232. Prentice-Hall, Engledwood Cliffs, N.J.

Wilcox-Lee, D. 1989. Introduction to L.H. Bailey. 1891. Some preliminatry studies on the influence of the electric arc lamp upon greenhouse plants. Cornell Univ. Agr. Expt. Sta. Bul. 30. In: J. Janick (ed.). Classic papers in horticultural science. p. 114-110. Prentice-Hall, Englewood Cliffs, N.J. 